\title{
Mechanism of ethylene oxychlorination over ruthenium oxide
}

\author{
M.D. Higham ${ }^{\text {a }}$, M. Scharfe ${ }^{\text {b }}$, M. Capdevila-Cortada ${ }^{\text {a }}$, J. Pérez-Ramírez ${ }^{\text {b,* }}$, N. López ${ }^{\text {a,* }}$ \\ a Institute of Chemical Research of Catalonia, ICIQ The Barcelona Institute of Science and Technology, Av. Països Catalans 16, 43007 Tarragona, Spain \\ ${ }^{\mathrm{b}}$ Institute for Chemical and Bioengineering, Department of Chemistry and Applied Biosciences, ETH Zurich, Vladimir-Prelog-Weg 1, 8093 Zurich, Switzerland
}

\begin{abstract}
A B S T R A C T
The oxychlorination of ethylene is an industrially relevant process within the manufacture of polyvinyl chloride (PVC). Although $\mathrm{RuO}_{2}$ is the best performing catalyst for the Deacon process $\left(4 \mathrm{HCl}+\mathrm{O}_{2} \rightarrow\right.$ $2 \mathrm{H}_{2} \mathrm{O}+2 \mathrm{Cl}_{2}$ ), experiments demonstrate a modest activity in the selective oxychlorination to vinyl chloride, favouring oxidation and polychlorinated saturated products. From the computational modelling three main contributions are found to control the performance: (i) coverage effects that alter the configuration of intermediates; (ii) the monodimensional arrangement of the active sites, in which the reaction of coadsorbed species works on a "first-come, first-served" basis; and (iii) the high reactivity of the oxygen species. Competition between oxidation and chlorination processes results in variable selectivity, depending on the reaction conditions (particularly temperature and reactant partial pressures), which influence the surface composition. From the analysis of the complex reaction network, the essential requirements for a good oxychlorination catalyst are formulated.
\end{abstract}

\section{Introduction}

$\mathrm{RuO}_{2}$ is an active catalytic material in a variety of processes, including catalytic $\mathrm{CO}$ [1-3], $\mathrm{NH}_{3}$ [4], alcohol [5], and $\mathrm{Hg}$ oxidation [6], as well as in electrochemical phenolic wastewater oxidation [7], or as an anode in water splitting cells [8]. In addition to its electrochemical applications [9,10], one of the most significant industrial uses of $\mathrm{RuO}_{2}$ is in $\mathrm{HCl}$ oxidation (Deacon process), where it is the best performing catalyst to produce molecular chlorine at low temperature [11-14]. Therefore, the chemistries of oxygen and chlorine on the $\mathrm{RuO}_{2}$ surfaces are intertwined, as evidenced by the linear scaling relationships ( $\mathrm{Cl}$ and $\mathrm{O}$ energies scale one with the other) $[15,16]$ and thus the material is prone to exhibit a complex selectivity behaviour. In fact, when seawater is employed in a $\mathrm{RuO}_{2}$-based electrochemical water splitting cell, the selectivity towards the $\mathrm{O}_{2}$ evolution reaction is compromised as $\mathrm{Cl}_{2}$ evolution emerges as a competitive path $[10,15,17,18]$.

Given this ability to activate adsorbates such as $\mathrm{HCl}, \mathrm{O}_{2}$, and hydrocarbons [19], $\mathrm{RuO}_{2}$ could potentially be a suitable catalyst for chlorination or oxychlorination reactions. This is especially relevant as polyvinyl chloride (PVC) production represented a market of 53 billion USD in 2015, still expected to grow at an annual rate of $5 \%$ in the coming years [20]. Therefore, vinyl chloride (VCM), the

\footnotetext{
* Corresponding authors.

E-mail addresses: jpr@chem.ethz.ch (J. Pérez-Ramírez), nlopez@iciq.es (N. López).
}

monomer of PVC or its intermediate 1,2-dichloroethane (commonly known as ethylene dichloride, EDC) are target synthetic platform molecules. To date, VCM is either produced through hydrochlorination of acetylene [21,22], or derived from EDC through energy-intensive thermal cracking [23]. The latter process releases $\mathrm{HCl}$ in equimolar amounts to $\mathrm{VCM}$, making $\mathrm{HCl}$ recovery crucial for sustainable large-scale PVC production. One way to recycle this $\mathrm{HCl}$ is by using it as a reactant together with $\mathrm{O}_{2}$ in ethylene oxychlorination in order to produce EDC (or directly VCM) $[13,23,24]$.

The current industrial catalyst for ethylene oxychlorination comprises cupric chloride $\left(\mathrm{CuCl}_{2}\right)$ as the active phase, impregnated on a porous support such as alumina, and promoted by numerous additives to reduce the metal loss and/or improve the activity and selectivity [25-28]. However, even though these cupric chloride catalysts are widely applied in industry due to their remarkable selectivity towards EDC (99\%), they still suffer from active phase volatilisation or particle stickiness [29]. Previous efforts to describe the mechanism of ethylene oxychlorination on classical $\mathrm{CuCl}_{2-}$ based catalysts usually included in situ and operando characterisation by XAFS, XANES, and IR or EPR spectroscopies [30-35]. Briefly, the process follows a redox mechanism in three steps: chlorination of ethylene by reduction of $\mathrm{CuCl}_{2}$ to $\mathrm{CuCl}$, that then forms a cupric oxychloride, and finally $\mathrm{CuCl}_{2}$ is recovered by re-chlorination of the oxychloride with $\mathrm{HCl}[24,26,27,30,31,33-43]$.

More recently, metal oxides like $\mathrm{RuO}_{2}$, $\mathrm{IrO}_{2}$, and $\mathrm{CeO}_{2}$ were reported as active but very diverse in selectivity $[44,45]$. Whilst 
$\mathrm{IrO}_{2}$ leads only to combustion of ethylene to $\mathrm{CO}$ and $\mathrm{CO}_{2}, \mathrm{RuO}_{2}$ and $\mathrm{CeO}_{2}$ exhibited formation of EDC and VCM (the combined selectivity at same conversion level of $10 \%$ is $10 \%$ and $98 \%$, respectively) along with $\mathrm{CO}_{x}$ [44]. Alternatively, some catalysts based on lanthanide oxychlorides were found active for one-step VCM synthesis, of which EuOCl emerged as an excellent oxychlorination catalyst, achieving a VCM selectivity up to $100 \%$, but at comparatively lower conversions [45]. Nevertheless, the mechanism of oxychlorination on these materials remains unknown, which hinders the catalyst design to overcome their specific drawbacks. A recent review highlights the challenges presented by catalytic oxyhalogenation processes [46].

In this study, we intend to shed light on the complex ethylene oxychlorination reaction network by combining state-of-the-art Density Functional Theory (DFT) calculations and a selected set of catalytic experiments to gain insight on the behaviour of $\mathrm{RuO}_{2}$ in a broad range of operating conditions. Thus far, there is no mechanistic study of oxides in ethylene oxychlorination and $\mathrm{RuO}_{2}$ presents a relatively uncomplicated electronic (conductive) and geometric (rutile) structure, allowing the extended investigation of the complete reaction network, which comprises (de-) chlorination, (de-)hydrogenation, and oxidation reactions (encompassing a total of 34 elementary steps). The main network characteristics could in the future be simplified when investigating other materials like $\mathrm{CeO}_{2}$ or $\mathrm{EuOCl}$, which are more appealing but present a more complex electronic structure. Furthermore, $\mathrm{RuO}_{2}$ exhibits both oxychlorination and combustion activity, making it an ideal system to investigate the interplay between these two competing processes. Whilst recent theoretical studies suggest that surface uptake of $\mathrm{Cl}$ by $\mathrm{RuO}_{2}$ is limited [47], previous combined experimental and theoretical investigations found that the $\mathrm{Cl}$ uptake is significant and does play some role in affecting $\mathrm{HCl}$ oxidation performance. Specifically, operando prompt gamma activation analysis (PGAA) studies show that under typical reaction conditions, $\mathrm{Cl}$ is present in considerable quantities in the catalyst sample $[48,49]$. Moreover, more recent theoretical ab initio thermodynamics studies suggest that the experimentally observed $\mathrm{Cl}$ uptake is limited to surface replacement of bridging oxygen atoms and the undercoordinated Ru positions and is present under typical reaction conditions [50]. Hence, whilst the kinetics of $\mathrm{RuO}_{2}$ in oxychlorination are as yet unknown, it is reasonable to assume that the degree of chlorination may very well play an important role in oxychlorination activity, as much as it is believed to affect $\mathrm{HCl}$ oxidation performance [48]. Moreover, oxychlorination has profited once before from the inheritance of the original Deacon catalyst [25-28] and bears the potential to profit again from the recent major leap in $\mathrm{HCl}$ oxidation, i.e. the implementation of outstanding low-temperature catalysts $\mathrm{RuO}_{2} / \mathrm{TiO}_{2}$-rutile and $\mathrm{RuO}_{2} / \mathrm{SnO}_{2}-$ cassiterite $[14,51]$. As such, this progress inspires the present work to develop a full understanding of ethylene oxychlorination on $\mathrm{RuO}_{2}$ and derive intrinsic requirements for a good VCM production catalyst.

\section{Materials and methods}

\subsection{Computational details}

Density Functional Theory (DFT) as implemented in the Vienna Ab initio Simulation Package (VASP), version 5.3.3, was applied to bulk $\mathrm{RuO}_{2}[52,53]$. The ionic positions and cell volume were optimised for a cell containing two formula units, using a planewave cut-off of $600 \mathrm{eV}$ and a k-point sampling mesh of $9 \times 9 \times 13$, employing the Monkhorst and Pack scheme [54]. The optimised bulk lattice parameters obtained $(a=b=4.520 \AA$, $c=3.118 \AA$ ) are in good agreement with experimental values obtained from single-crystal X-ray diffraction; the difference between calculated lattice parameters and the experimental values is less than $0.7 \%$ [55]. From the optimised bulk structure, slabs representing the lowest energy rutile $(110)$ facet of $\mathrm{RuO}_{2}$ were constructed. Previous works have established that the $(110)$ facet is the most stable, and hence it forms the largest contribution to the surface of polycrystalline $\mathrm{RuO}_{2}$, therefore being the most representative of the main component of surface activity [56]. A $p(4 \times 1)$ supercell was employed, with a k-point sampling of $2 \times 4 \times 1$. A slab consisting of five layers, interleaved by $15 \AA$ of vacuum, was used. The top two layers of the slab were optimised, whilst the remaining bottom three were fixed. Two distinct surface environments were identified for both Ru and O (Fig. S1). Oxygen atoms are present as rows of 2-coordinate "bridging" oxygen atoms $\left(\mathrm{O}_{\mathrm{b}}\right)$ on the surface, as well as 3-coordinate atoms lying within the plane of the surface. For Ru, 6-coordinate centres are present located beneath the $\mathrm{O}_{\mathrm{b}}$ atoms, whilst 5-coordinate unsatured sites $\left(\mathrm{Ru}_{\text {cus }}\right)$ provide the main adsorption sites for catalytic activity. Owing to their coordinatively unsaturated nature, the $\mathrm{O}_{\mathrm{b}}$ and $\mathrm{Ru}_{\text {cus }}$ sites play the most important roles in catalysis. Forces were converged to within $0.015 \mathrm{eV}^{-1}$. In order to eliminate the spurious electrostatic interactions associated with asymmetric relaxation of the slab, a dipole correction was applied to the vacuum. The Perdew-Burke-Ernzerhof (PBE) exchange-correlation functional was employed throughout [57]. Inner electrons were replaced with projector augmented-wave (PAW) [58], and the valance states were expanded in plane-waves with a cut-off energy of $450 \mathrm{eV}$. The chosen functionals provide a reasonable reproduction of experimental results [48,59]. Transition states were identified using the climbing image nudged elastic band (CI-NEB) method [60], and vibrational analyses performed numerically with a step of $0.015 \AA$. Structures are available through the ioChem-BD repository $[61,62]$.

To analyse the complete reaction network, a simple microkinetic (MK) model was set up based on our previous models for the Deacon reaction [49]. Rate coefficients of the elementary steps were determined using the thermodynamic and kinetic parameters obtained from the DFT calculations. The gas-phase entropies were taken from the NIST database [63], the attempt frequency for the rate calculations was set to $10^{13}$ for simplicity, and the Knudsen equation was taken for adsorption. Then MK simulations were performed using a batch-model reactor; further details can be found in Ref. [49]. In the MK simulations, the initial relative pressures and temperatures correspond to those employed experimentally, and the initial conditions are described in the text. The reaction order of $\mathrm{HCl}$ at the experimental $623 \mathrm{~K}$ conditions was derived from the MK models.

\subsection{Experimental details}

Commercial $\mathrm{RuO}_{2}$ (Sigma-Aldrich, 99.9\%) was calcined at $723 \mathrm{~K}$ in static air using a heating rate of $5 \mathrm{~K} \mathrm{~min}^{-1}$ and an isothermal step of $5 \mathrm{~h}$ prior to its catalytic evaluation. The gas-phase $\mathrm{HCl}$ oxidation and ethylene oxychlorination were investigated at ambient pressure in a continuous-flow fixed-bed reactor. The set-up consists of $(i)$ mass flow controllers to feed $\mathrm{C}_{2} \mathrm{H}_{4}$ (PanGas, $20.15 \%$ in $\mathrm{He}$ ), $\mathrm{HCl}$ (Air Liquide, purity 2.8, anhydrous), $\mathrm{O}_{2}$ (Messer, $10.06 \%$ in $\mathrm{He}$ ), $\mathrm{He}$ (PanGas, purity 5.0) as a carrier gas, and $\mathrm{Ar}$ (PanGas, purity 5.0) as an internal standard; (ii) an electrically heated oven hosting a quartz micro-reactor equipped with a K-type thermocouple whose tip reaches the centre of the catalyst bed; (iii) downstream heat tracing to avoid any condensation of the reactants and products; and (iv) a gas chromatograph coupled to a mass spectrometer (GC-MS) for on-line analysis. The effluent stream was neutralised by passing it through an impinging bottle containing an aqueous $\mathrm{NaOH}$ solution $(1 \mathrm{M})$. The catalyst $\left(W_{\text {cat }}=0.5 \mathrm{~g}\right.$, 
particle size, $\left.d_{\mathrm{p}}=0.4-0.6 \mathrm{~mm}\right)$, diluted with quartz particles $\left(W_{\text {quartz }}=2.5 \mathrm{~g}, d_{\mathrm{p}}=0.2-0.3 \mathrm{~mm}\right.$, calcined at $\left.1173 \mathrm{~K}\right)$ was loaded in the micro-reactor (10 $\mathrm{mm}$ inner diameter) and pretreated in He at $473 \mathrm{~K}$ for $30 \mathrm{~min}$. Thereafter, a total flow $\left(F_{\mathrm{T}}\right)$ of $100 \mathrm{~cm}^{3}$ STP $\min ^{-1}$ containing 3 vol\% $\mathrm{C}_{2} \mathrm{H}_{4}, 1-9$ vol\% $\mathrm{HCl}, 0-6$ vol\% $\mathrm{O}_{2}$, and $3 \mathrm{vol} \% \mathrm{Ar}$, balanced in He was fed to the reactor at a bed temperature $(T)$ of $460-773 \mathrm{~K}$ and pressure $(P)$ of 1 bar. Note that relatively low feed concentrations were selected to prevent corrosion, enable safe handling, and minimise the formation of hot spots in the catalyst bed due to the high reaction exothermicity. The standard conditions of $3 \mathrm{vol} \% \mathrm{C}_{2} \mathrm{H}_{4}, 3 \mathrm{vol} \% \mathrm{HCl}$, and $1.5 \mathrm{vol} \% \mathrm{O}_{2}$ were chosen to reflect the reaction stoichiometry to form VCM (see Eq. (5), Table 1). Prior to the analysis of the reaction mixtures, the catalysts were equilibrated for at least $1 \mathrm{~h}$ under each condition. The gas composition at the reactor outlet containing reactants $\left(\mathrm{C}_{2} \mathrm{H}_{4}, \mathrm{O}_{2}, \mathrm{HCl}\right)$ and products (EDC, VCM, $\mathrm{CO}, \mathrm{CO}_{2}$, ethyl chloride (EC), 1,2dichloroethene (1,2-DCE)) was analysed online using a gas chromatograph equipped with a GS-CarbonPLOT column coupled to a mass spectrometer (Agilent GC 7890B, Agilent MSD 5977A) with a triple-axis detector and an electron multiplier. In the oxidation tests, $\mathrm{HCl}(3 \mathrm{vol} \%)$ and $\mathrm{O}_{2}$ were fed in a $1: 2$ volumetric ratio. The $\mathrm{Cl}_{2}$ production was quantified by offline iodometric titration (using a Mettler Toledo G20 Compact Titrator) of triiodide, formed by purging the $\mathrm{Cl}_{2}$ containing reactor outlet through an aqueous $\mathrm{KI}$ (Sigma-Aldrich, $99.5 \%)$ solution $(0.1 \mathrm{M})$, with $0.01 \mathrm{M}$ sodium thiosulfate solution (Sigma-Aldrich, 99.99\%). Further details on the calculation of conversions and selectivities are given in the Supplementary Material.

\section{Results}

As shown in Table 1, the reactions above differ in the stoichiometry for $\mathrm{O}_{2}$ and $\mathrm{HCl}$. Among them, the most exothermic one is the irreversible oxidation of ethylene, thus this process represents a thermodynamic sink, whilst the formation of EDC, VCM, and 1,2DCE are exothermic by a similar amount, much higher than $\mathrm{HCl}$ oxidation. In the following, we will analyse the reaction schemes that drive the selectivity of the reaction network, first by describing the experimental data for $\mathrm{RuO}_{2}$, making comparison with other well-known Deacon catalysts, and then by the detailed evaluation of the reaction profile through first-principles simulations.

In order to link $\mathrm{HCl}$ oxidation and ethylene oxychlorination behaviour, both processes were compared in a continuous-flow fixed-bed reactor at a temperature $T_{20}$, where the catalyst reaches $20 \%( \pm 1 \%)$ conversion in the respective reactions (Fig. 1a). The $T_{20}$ of ethylene oxychlorination over $\mathrm{RuO}_{2}$ is $623 \mathrm{~K}$, substantially higher than for the Deacon process ( $462 \mathrm{~K}$ ). A stability test confirmed the catalyst stability of the discussed ethylene oxychlorination conditions at $623 \mathrm{~K}$, exhibiting constant conversion and selectivities during $50 \mathrm{~h}$ (Fig. S2a). In addition, previous work showed that bulk $\mathrm{RuO}_{2}$ continues to perform well as a $\mathrm{HCl}$ oxidation catalyst up to $673 \mathrm{~K}$ [56]. Comparatively, $\mathrm{RuO}_{2}$ is more active than $\mathrm{IrO}_{2}$ or $\mathrm{CeO}_{2}$ for both processes, especially for $\mathrm{HCl}$ oxidation
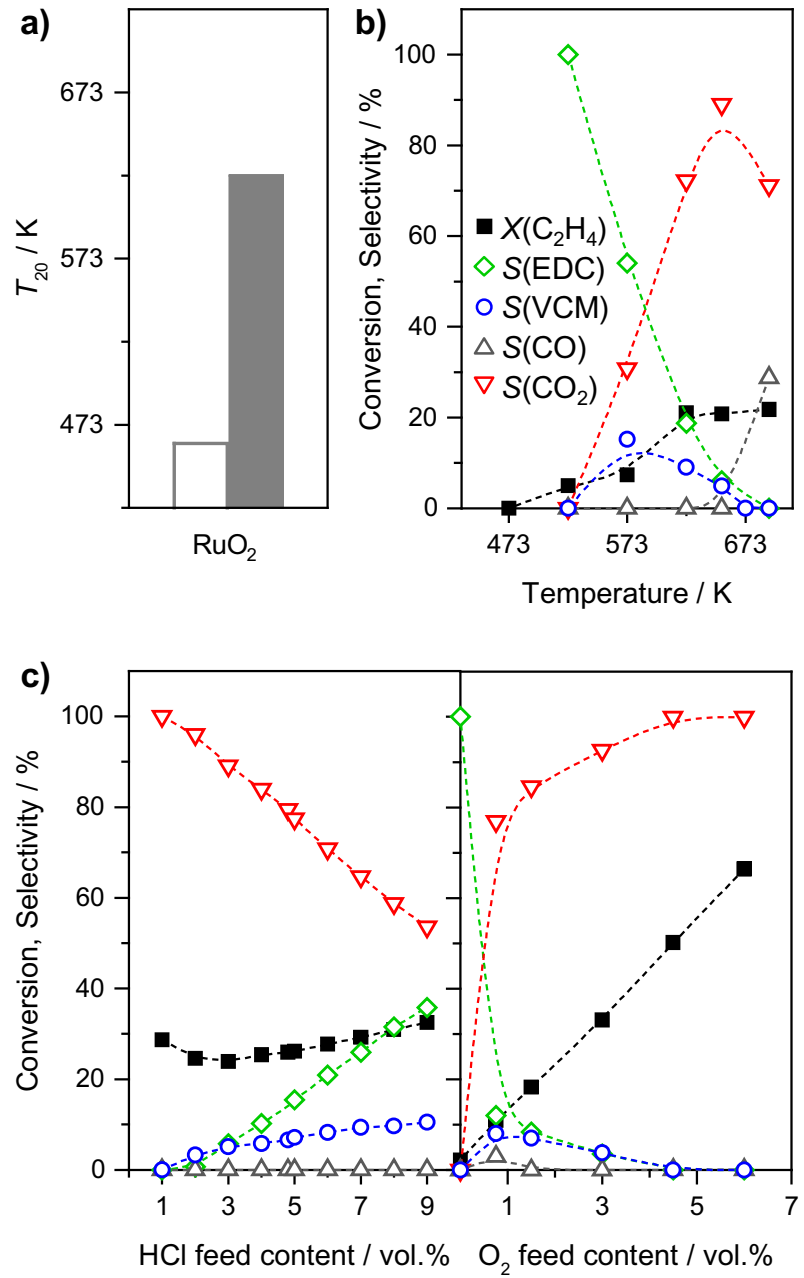

Fig. 1. (a) $T_{20}$ of $\mathrm{HCl}$ oxidation (white bar) and ethylene oxychlorination (grey bar) over $\mathrm{RuO}_{2}$. Conditions: $W_{\text {cat }}=0.5 \mathrm{~g} ; F_{\mathrm{T}}=100 \mathrm{~cm}^{3} \mathrm{STP} \mathrm{min}^{-1}$ containing $3 \mathrm{vol} \% \mathrm{HCl}$ and 6 vol\% $\mathrm{O}_{2}$ for $\mathrm{HCl}$ oxidation, 3 vol\% $\mathrm{C}_{2} \mathrm{H}_{4}, 3 \mathrm{vol} \% \mathrm{HCl}$, and $1.5 \mathrm{vol} \% \mathrm{O}_{2}$ for oxychlorination at $P=1 \mathrm{bar}$, each point was stabilised for $2 \mathrm{~h}$ on stream. Conversion and selectivity versus (b) temperature with $3 \mathrm{vol} \% \mathrm{C}_{2} \mathrm{H}_{4}, 3 \mathrm{vol} \% \mathrm{HCl}$, and $1.5 \mathrm{vol} \% \mathrm{O}_{2}$, and (c) volumetric $\mathrm{HCl}$ and $\mathrm{O}_{2}$ feed contents at $T=623 \mathrm{~K}$ with 3 vol\% $\mathrm{C}_{2} \mathrm{H}_{4}, 1-9$ vol\% $\mathrm{HCl}, 1.5$ vol\% $\mathrm{O}_{2}$ and 3 vol\% $\mathrm{C}_{2} \mathrm{H}_{4}, 3$ vol\% $\mathrm{HCl}, 0-6$ vol\% $\mathrm{O}_{2}$. Other conditions as in (a).

$[44,45,64]$. In terms of selectivity, $\mathrm{RuO}_{2}$ exhibits mostly combustion to $\mathrm{CO}_{2}$, but also shows some a limited degree of chlorinated hydrocarbon formation (Fig. 1b). By comparison, $\mathrm{IrO}_{2}$, the least active, exhibits purely combustion of $\mathrm{C}_{2} \mathrm{H}_{4}$ to $\mathrm{CO}$, and $\mathrm{CO}_{2}$ (the major product). $\mathrm{CeO}_{2}$, like $\mathrm{RuO}_{2}$, shows formation of both combustion products and chlorinated hydrocarbons, with selectivity towards EDC prevailing [44]. None of the three catalysts exhibit $\mathrm{Cl}_{2}$ formation under oxychlorination conditions, but most likely for different reasons. On $\mathrm{IrO}_{2}$ and $\mathrm{RuO}_{2}$, consumption of $\mathrm{O}_{2}$ for combustion is strongly favoured over $\mathrm{HCl}$ oxidation, whilst on

Table 1

List of reactions that take place competitively on the surface of the catalyst and their entalpies as obtained from the NIST database [63].

\begin{tabular}{|c|c|c|c|}
\hline No. & Reaction & Equation & $\Delta \mathrm{H} / \mathrm{kJ} \mathrm{mol}^{-1}$ \\
\hline 1 & $\mathrm{HCl}$ oxidation & $4 \mathrm{HCl}+\mathrm{O}_{2} \rightarrow 2 \mathrm{Cl}_{2}+2 \mathrm{H}_{2} \mathrm{O}$ & -114 \\
\hline 2 & Ethylene oxidation & $\mathrm{C}_{2} \mathrm{H}_{4}+3 \mathrm{O}_{2} \rightarrow 2 \mathrm{CO}_{2}+2 \mathrm{H}_{2} \mathrm{O}$ & -1323 \\
\hline 3 & EC synthesis & $\mathrm{C}_{2} \mathrm{H}_{4}+\mathrm{HCl} \rightarrow \mathrm{C}_{2} \mathrm{H}_{5} \mathrm{Cl}$ & -69 \\
\hline 4 & EDC synthesis & $\mathrm{C}_{2} \mathrm{H}_{4}+{ }^{1} /{ }_{2} \mathrm{O}_{2}+2 \mathrm{HCl} \rightarrow \mathrm{C}_{2} \mathrm{H}_{4} \mathrm{Cl}_{2}+\mathrm{H}_{2} \mathrm{O}$ & -242 \\
\hline 5 & VCM synthesis & $\mathrm{C}_{2} \mathrm{H}_{4}+{ }^{1} /{ }_{2} \mathrm{O}_{2}+\mathrm{HCl} \rightarrow \mathrm{C}_{2} \mathrm{H}_{3} \mathrm{Cl}+\mathrm{H}_{2} \mathrm{O}$ & -180 \\
\hline 6 & 1,2-DCE (Z/E) synthesis & $\mathrm{C}_{2} \mathrm{H}_{4}+\mathrm{O}_{2}+2 \mathrm{HCl} \rightarrow \mathrm{C}_{2} \mathrm{H}_{2} \mathrm{Cl}_{2}+2 \mathrm{H}_{2} \mathrm{O}$ & -353 \\
\hline 7 & EDC dehydrochlorination & $\mathrm{C}_{2} \mathrm{H}_{4} \mathrm{Cl}_{2} \rightarrow \mathrm{C}_{2} \mathrm{H}_{3} \mathrm{Cl}+\mathrm{HCl}$ & +62 \\
\hline
\end{tabular}


$\mathrm{CeO}_{2}$ most of the $\mathrm{Cl}$ is consumed in the formation of EDC and VCM under these conditions $(\mathrm{HCl}$ is substoichiometric with respect to EDC). This result, in addition to previous works [19,44,45,64], suggests that contrary to expectations, a good Deacon catalyst may not necessarily be a good oxychlorination catalyst, but the reasons behind this were not investigated. Thus, we picked the best Deacon catalyst, $\mathrm{RuO}_{2}$, which exhibits only moderate oxychlorination performance, for further investigation in order to identify the limitations.

A variation of temperature from $693 \mathrm{~K}$ to $473 \mathrm{~K}$ (Fig. 1b) revealed that the conversion stays constant at about $20 \%$ until $623 \mathrm{~K}$ before it significantly drops to $7 \%$ and less. At high temperatures, combustion products dominate, with $\mathrm{CO}$ only being formed at the highest investigated temperature, whilst at low temperature until $523 \mathrm{~K}$ only EDC is observed. Even though VCM formation is favoured at higher temperatures in ethylene oxychlorination (Fig. S2), it is formed only in the temperature window of 523$653 \mathrm{~K}$, exhibiting a maximum at $573 \mathrm{~K}$. Considering the temperature with still significant VCM formation and already about $20 \%$ conversion $(623 \mathrm{~K})$, the $\mathrm{HCl}$ feed content was varied from 1 to $9 \mathrm{vol} \%$, in order to achieve a similar coverage history of the sample from low to high chlorine coverage as in the temperature variation.

Across the range of feed $\mathrm{HCl}$ concentrations, the conversion stays approximately constant, exhibiting a small minimum at $3 \mathrm{vol} \% \mathrm{HCl}$ (Fig. 1c). With rising $\mathrm{HCl}$ content, the selectivity to $\mathrm{CO}_{2}$ is decreased linearly (order -1 with respect to $\mathrm{HCl}$ ) and the selectivity to EDC shows a first order dependence to $\mathrm{HCl}$. VCM exhibits a first order behaviour as well, although with a lower slope with respect to EDC. The formation of $\mathrm{CO}$ is not observed. In $\mathrm{HCl}$ oxidation the conversion was found to exhibit a 0.2 order on $\mathrm{HCl}$ [49].

In order to rationalise the experimentally observed temperature and input feed composition dependence of the catalyst selectivity, DFT calculations were performed simulating the surface under low $\mathrm{Cl}$ coverage conditions, probing the energetics of the relevant elementary processes. A large reaction network was studied, considering processes involving both chlorination and oxidation of $\mathrm{C}_{2} \mathrm{H}_{4}$, separately and in conjunction. Deacon-type processes take place under the reaction conditions, with $\mathrm{HCl}$ and $\mathrm{O}_{2}$ dissociative adsorption being prerequisites for further reaction with $\mathrm{C}_{2} \mathrm{H}_{4}$, as well as $\mathrm{HCl}$ being oxidised by $\mathrm{O}_{2}$ to $\mathrm{Cl}_{2}$ and $\mathrm{H}_{2} \mathrm{O}$ as in the standard Deacon process. A summary of the complete reaction network is presented in Fig. 2.

Firstly, the processes that are common to both the Deacon and oxychlorination reactions are summarised in Table 2 and denoted by Roman numerals. Adsorption of $\mathrm{O}_{2}$ is exothermic by $-1.20 \mathrm{eV}$ (process I, Table 2), with subsequent dissociation to $20^{* *}$ also being exothermic by an extra $-0.74 \mathrm{eV}$ with an activation barrier of 0.28 $\mathrm{eV}$ (process II, Table 2). Dissociative adsorption of $\mathrm{HCl}$ is exothermic by $-1.79 \mathrm{eV}$ (process III, Table 2), with $\mathrm{H}$ being abstracted by bridging $\mathrm{O}$ atoms $\left(\mathrm{O}_{\mathrm{b}}\right)$ present on the catalyst surface. In the Deacon process, $\mathrm{Cl}$ recombination yields the product $\mathrm{Cl}_{2}$ which subsequently desorbs from the surface (process IV, Table 2). Surface $\mathrm{H}$ arising from $\mathrm{HCl}$ dissociative adsorption leaves the surface in the form of water, with $\mathrm{H}$ transferring from bridging $\mathrm{O}$ sites

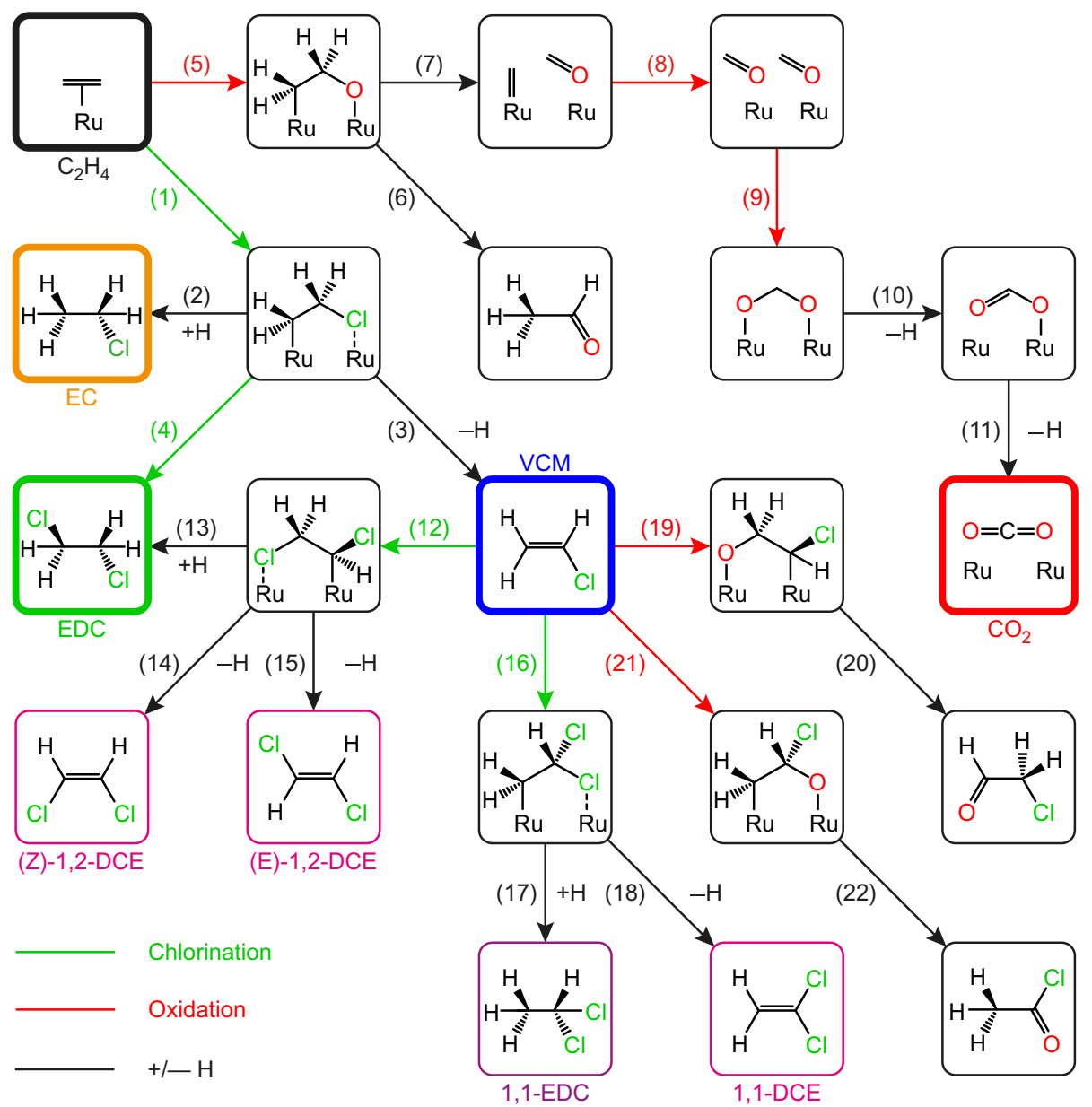

Fig. 2. Reaction network for the processes investigated. Deacon-type processes, which are common to all of the reaction pathways, are omitted for clarity. Adsorption and desorption processes are omitted for similar reasons. Numbers refer to processes in Table 2. Possible end products are color-coded. The starting point $\left(\mathrm{C}_{2} \mathrm{H}_{4}^{*}\right)$ and the observed products are also indicated with bold boxes. 
Table 2

Reaction and activation energies $\left(\Delta E\right.$ and $E_{a}$, in $\left.\mathrm{eV}\right)$ for various elementary steps and imaginary frequencies $\left(\mathrm{cm}^{-1}\right)$ of the corresponding transition states.

\begin{tabular}{|c|c|c|c|c|}
\hline No. & Reaction & $\Delta E$ & $E_{a}$ & $v_{i}$ \\
\hline & $\mathrm{HCl}$ oxidation & & & \\
\hline I & $\mathrm{O}_{2}+2^{*} \rightarrow \mathrm{O}_{2}^{* *}$ & -1.20 & - & - \\
\hline II & $\mathrm{O}_{2}^{* *} \rightarrow 2 \mathrm{O}^{*}$ & -0.74 & 0.28 & 538 \\
\hline III & $\mathrm{HCl}+\mathrm{O}_{\mathrm{b}}+{ }^{*} \rightarrow \mathrm{Cl}^{*}+\mathrm{O}_{\mathrm{b}} \mathrm{H}$ & -1.79 & - & - \\
\hline IV & $\mathrm{Cl}^{*}+\mathrm{Cl}^{*} \rightarrow \mathrm{Cl}_{2}+2^{*}$ & +2.23 & - & - \\
\hline $\mathrm{V}$ & $\mathrm{O}^{*}+\mathrm{O}_{\mathrm{b}} \mathrm{H} \rightarrow \mathrm{OH}^{*}+\mathrm{O}_{\mathrm{b}}$ & -0.02 & 0.35 & 1073 \\
\hline VI & $\mathrm{OH}^{*}+\mathrm{O}_{\mathrm{b}} \mathrm{H} \rightarrow \mathrm{H}_{2} \mathrm{O}^{*}+\mathrm{O}_{\mathrm{b}}$ & -0.11 & 0.18 & 845 \\
\hline \multirow[t]{2}{*}{ VII } & $\mathrm{H}_{2} \mathrm{O}^{*} \rightarrow \mathrm{H}_{2} \mathrm{O}+*$ & +1.12 & - & - \\
\hline & $\mathrm{C}_{2} \mathrm{H}_{4}$ chlorination & & & \\
\hline A1 & $\mathrm{C}_{2} \mathrm{H}_{4}+* \rightarrow \mathrm{C}_{2} \mathrm{H}_{4}^{*}$ & -0.66 & - & - \\
\hline 1 & $\mathrm{C}_{2} \mathrm{H}_{4}^{*}+\mathrm{Cl}^{*} \rightarrow \mathrm{C}_{2} \mathrm{H}_{4} \mathrm{Cl}^{*}+*$ & +0.14 & 0.26 & 201 \\
\hline 2 & $\mathrm{C}_{2} \mathrm{H}_{4} \mathrm{Cl}^{*}+\mathrm{O}_{\mathrm{b}} \mathrm{H} \rightarrow \mathrm{C}_{2} \mathrm{H}_{5} \mathrm{Cl}^{*}+\mathrm{O}_{\mathrm{b}}$ & +0.23 & 0.96 & 1345 \\
\hline $\mathrm{A} 2$ & $\mathrm{C}_{2} \mathrm{H}_{5} \mathrm{Cl}^{*} \rightarrow \mathrm{C}_{2} \mathrm{H}_{5} \mathrm{Cl}+{ }^{*}$ & +0.61 & - & - \\
\hline 3 & $\mathrm{C}_{2} \mathrm{H}_{4} \mathrm{Cl}^{*}+\mathrm{O}_{\mathrm{b}} \rightarrow \mathrm{VCM}^{*}+\mathrm{O}_{\mathrm{b}} \mathrm{H}$ & -0.21 & 1.07 & 1555 \\
\hline A3 & $\mathrm{VCM}^{*} \rightarrow \mathrm{VCM}+*$ & +0.88 & - & - \\
\hline $4 a$ & $\mathrm{C}_{2} \mathrm{H}_{4} \mathrm{Cl}^{*}+\mathrm{Cl}^{*} \rightarrow \mathrm{EDC}^{*}+*$ & +0.17 & 1.85 & 193 \\
\hline $4 b^{\dagger}$ & $\mathrm{C}_{2} \mathrm{H}_{4} \mathrm{Cl}^{*}+\mathrm{Cl}^{*} \rightarrow \mathrm{EDC}^{*}+*$ & -0.87 & 0.00 & - \\
\hline \multirow[t]{2}{*}{ A4 } & $\mathrm{EDC}^{*} \rightarrow \mathrm{EDC}+*$ & +0.71 & - & - \\
\hline & $\mathrm{C}_{2} \mathrm{H}_{4}$ oxidation & & & \\
\hline 5 & $\mathrm{C}_{2} \mathrm{H}_{4}^{*}+\mathrm{O}^{*} \rightarrow \mathrm{OMME}^{* *}$ & -0.55 & 0.35 & 261 \\
\hline 6 & $\mathrm{OMME}^{* *} \rightarrow \mathrm{CH}_{3} \mathrm{CHO}^{*}+*$ & -0.88 & 1.22 & 990 \\
\hline A5 & $\mathrm{CH}_{3} \mathrm{CHO}^{*} \rightarrow \mathrm{CH}_{3} \mathrm{CHO}+*$ & +0.90 & - & - \\
\hline 7 & $\mathrm{OMME}^{* *} \rightarrow \mathrm{CH}_{2}^{*}+\mathrm{H}_{2} \mathrm{CO}^{*}$ & +0.96 & 1.06 & 71 \\
\hline 8 & $\mathrm{CH}_{2}^{*}+\mathrm{O}^{*} \rightarrow \mathrm{H}_{2} \mathrm{CO}^{*}+*$ & -1.30 & 0.02 & 71 \\
\hline 9 & $\mathrm{H}_{2} \mathrm{CO}^{*}+\mathrm{O}^{*} \rightarrow \mathrm{OCH}_{2} \mathrm{O}^{* *}$ & -0.89 & 0.00 & - \\
\hline 10 & $\mathrm{OCH}_{2} \mathrm{O}^{* *}+\mathrm{O}_{\mathrm{b}} \rightarrow \mathrm{OCHO}^{*}+\mathrm{O}_{\mathrm{b}} \mathrm{H}+*$ & -2.30 & 0.54 & 1358 \\
\hline $11 \mathrm{a}$ & $\mathrm{OCHO}^{*}+\mathrm{O}_{\mathrm{b}} \rightarrow \mathrm{CO}_{2}^{*}+\mathrm{O}_{\mathrm{b}} \mathrm{H}$ & -0.04 & 1.70 & 1169 \\
\hline $11 b^{\dagger}$ & $\mathrm{OCHO}^{*}+\mathrm{O}_{\mathrm{b}} \rightarrow \mathrm{CO}_{2}^{*}+\mathrm{O}_{\mathrm{b}} \mathrm{H}$ & -2.09 & 0.00 & - \\
\hline \multirow[t]{2}{*}{ A6 } & $\mathrm{CO}_{2}^{*} \rightarrow \mathrm{CO}_{2}+*$ & 0.20 & - & - \\
\hline & VCM chlorination & & & \\
\hline 12 & $\mathrm{VCM}^{*}+\mathrm{Cl}^{*} \rightarrow \mathrm{ClCHCH}_{2} \mathrm{Cl}^{*}+*$ & +0.56 & 1.09 & 248 \\
\hline 13 & $\mathrm{ClCHCH}_{2} \mathrm{Cl}^{*}+\mathrm{O}_{\mathrm{b}} \mathrm{H} \rightarrow \mathrm{EDC}^{*}+\mathrm{O}_{\mathrm{b}}$ & +0.47 & 1.18 & 1307 \\
\hline 14 & $\mathrm{ClCHCH}_{2} \mathrm{Cl}^{*}+\mathrm{O}_{\mathrm{b}} \rightarrow \mathrm{Z}-\mathrm{C}_{2} \mathrm{H}_{2} \mathrm{Cl}_{2}^{*}+\mathrm{O}_{\mathrm{b}} \mathrm{H}$ & -0.16 & 1.37 & 892 \\
\hline A7 & $\mathrm{Z}-\mathrm{C}_{2} \mathrm{H}_{2} \mathrm{Cl}_{2}^{*} \rightarrow \mathrm{Z}-\mathrm{C}_{2} \mathrm{H}_{2} \mathrm{Cl}_{2}+*$ & +0.32 & - & - \\
\hline 15 & $\mathrm{ClCHCH}_{2} \mathrm{Cl}^{*}+\mathrm{O}_{\mathrm{b}} \rightarrow \mathrm{E}-\mathrm{C}_{2} \mathrm{H}_{2} \mathrm{Cl}_{2}^{*}+\mathrm{O}_{\mathrm{b}} \mathrm{H}$ & -0.15 & 0.97 & 1429 \\
\hline A8 & $\mathrm{E}-\mathrm{C}_{2} \mathrm{H}_{4} \mathrm{Cl}_{2}^{*} \rightarrow \mathrm{E}-\mathrm{C}_{2} \mathrm{H}_{2} \mathrm{Cl}_{2}+*$ & +0.53 & - & - \\
\hline 16 & $\mathrm{VCM}^{*}+\mathrm{Cl}^{*} \rightarrow \mathrm{CH}_{2} \mathrm{CHCl}_{2}^{*}+*$ & +0.72 & 0.99 & 207 \\
\hline 17 & $\mathrm{CH}_{2} \mathrm{CHCl}_{2}^{*}+\mathrm{O}_{\mathrm{b}} \mathrm{H} \rightarrow \mathrm{CH}_{3} \mathrm{CHCl}_{2}^{*}+\mathrm{O}_{\mathrm{b}}$ & +0.25 & 0.99 & 1314 \\
\hline A9 & $\mathrm{CH}_{3} \mathrm{CHCl}_{2}^{*} \rightarrow \mathrm{CH}_{3} \mathrm{CHCl}_{2}+*$ & +0.53 & - & - \\
\hline 18 & $\mathrm{CH}_{2} \mathrm{CHCl}_{2}^{*}+\mathrm{O}_{\mathrm{b}} \rightarrow \mathrm{CH}_{2} \mathrm{CCl}_{2}^{*}+\mathrm{O}_{\mathrm{b}} \mathrm{H}$ & -0.25 & 1.39 & 1407 \\
\hline \multirow[t]{2}{*}{ A10 } & $\mathrm{CH}_{2} \mathrm{CCl}_{2}^{*} \rightarrow \mathrm{CH}_{2} \mathrm{CCl}_{2}+*$ & +0.54 & - & - \\
\hline & VCM oxidation & & & \\
\hline 19 & $\mathrm{VCM}^{*}+\mathrm{O}^{*} \rightarrow \mathrm{OCH}_{2} \mathrm{CHCl}^{* *}$ & -0.04 & 0.98 & 323 \\
\hline 20 & $\mathrm{OCH}_{2} \mathrm{CHCl}^{* *} \rightarrow \mathrm{CH}_{2} \mathrm{ClCHO}^{*}+*$ & -1.05 & 1.10 & 946 \\
\hline A11 & $\mathrm{CH}_{2} \mathrm{ClCHO}^{*} \rightarrow \mathrm{CH}_{2} \mathrm{ClCHO}+*$ & +1.13 & - & - \\
\hline 21 & $\mathrm{VCM}^{*}+\mathrm{O}^{*} \rightarrow \mathrm{CH}_{2} \mathrm{CHClO}^{* *}$ & -0.27 & 0.73 & 272 \\
\hline 22 & $\mathrm{CH}_{2} \mathrm{CHClO}^{* *} \rightarrow \mathrm{CH}_{3} \mathrm{COCl}^{*}+*$ & -1.23 & 1.19 & 1118 \\
\hline A12 & $\mathrm{CH}_{3} \mathrm{COCl}^{*} \rightarrow \mathrm{CH}_{3} \mathrm{COCl}+*$ & +0.72 & - & - \\
\hline
\end{tabular}

${ }^{\dagger}$ High coverage. Structures are available through the ioChem-BD repository [62].

$\left(\mathrm{O}_{\mathrm{b}}\right)$ to coadsorbed $\mathrm{O}\left(\mathrm{O}_{\text {cus }}\right)$ to generate $\mathrm{O}_{\text {cus }} \mathrm{H}$ (process $\mathrm{V}$, Table 2 ), followed by a second $\mathrm{H}$ transfer to yield $\mathrm{H}_{2} \mathrm{O}$ (process VI, Table 2) which then desorbs from the surface (process VII, Table 2). Both $\mathrm{H}$ transfer processes have mildly exothermic reaction energies $(-0.02 \mathrm{eV}$ and $-0.11 \mathrm{eV}$ for processes $\mathrm{V}$ and $\mathrm{VI}$, respectively) and comparable low activation energies $(0.35 \mathrm{eV}$ and $0.18 \mathrm{eV}$ for processes $\mathrm{V}$ and VI, respectively). Desorption of $\mathrm{H}_{2} \mathrm{O}$ is endothermic by $1.12 \mathrm{eV}$ (process VII, Table 2). Our results are thus in line with previous calculations $[2,56,65-68]$. A recent theoretical work identifies that water evolution is a key process in $\mathrm{HCl}$ oxidation, acting as an energetic bottleneck for the overall reaction [47]. However, with regards to ethylene oxychlorination, eventual evolution of water is a common process to all of the possible reactions, and hence will not have any appreciable impact on selectivity of the chlorinated products.

The addition of ethylene further expands the list of competitive

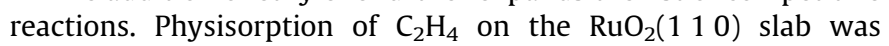
determined to be exothermic by $-0.66 \mathrm{eV}$ (process A1, Table 2).
Subsequently, addition across the $\mathrm{C}=\mathrm{C}$ bond can occur with either coadsorbed $\mathrm{Cl}$ or $\mathrm{O}$ occupying adjacent adsorption sites to $\mathrm{C}_{2} \mathrm{H}_{4}$, yielding intermediates bound to the surface. The chlorination route (process 1 , Table 2) is endothermic whilst the oxidation route (process 5, Table 2) is exothermic $\left(\Delta E_{\mathrm{Cl}}=0.14 \mathrm{eV}\right.$, compared to $\Delta E_{\mathrm{O}}=-0.55 \mathrm{eV}$ ). On the other hand, chlorination has a slightly lower activation barrier than oxidation $\left(E_{\mathrm{a}, \mathrm{Cl}}=0.26 \mathrm{eV}\right.$ compared to $E_{\mathrm{a}, \mathrm{O}}=0.35 \mathrm{eV}$ ). Hence, competition exists between the two processes, and the product distribution will vary depending on whether the system is under kinetic or thermodynamic control.

The chlorination pathway begins with the formation of a $\mathrm{ClCH}_{2}-$ $\mathrm{CH}_{2}^{*}$ intermediate (process 1 , Table 2). From here, a number of processes can take place. Firstly, direct protonation of the $\mathrm{ClCH}_{2} \mathrm{CH}_{2}^{*}$ intermediate from $\mathrm{O}_{\mathrm{b}} \mathrm{H}$ can occur (process 2, Table 2), yielding ethyl chloride $\left(\mathrm{C}_{2} \mathrm{H}_{5} \mathrm{Cl}\right)$; this process was found to possess a feasible activation barrier $\left(E_{\mathrm{a}}=0.96 \mathrm{eV}\right)$ but was also calculated to be slightly endothermic $(\Delta E=0.26 \mathrm{eV})$. Desorption of $\mathrm{C}_{2} \mathrm{H}_{5} \mathrm{Cl}$ is endothermic by $0.61 \mathrm{eV}$ (process A2, Table 2). A second alternative 
is VCM generation by $\mathrm{H}$ abstraction from the $\mathrm{ClCH}_{2} \mathrm{CH}_{2}^{*}$ intermediate (process 3 , Table 2 ); this process is both exothermic and kinetically feasible $\left(\Delta E=-0.21 \mathrm{eV}, E_{\mathrm{a}}=1.07 \mathrm{eV}\right)$. Desorption of VCM from the surface is endothermic by $0.88 \mathrm{eV}$ (process $\mathrm{A} 3$, Table 2). Finally, direct chlorination of the $\mathrm{ClCH}_{2} \mathrm{CH}_{2} *$ intermediate yields the product EDC; the process was found to be slightly endothermic $(\Delta E=0.17 \mathrm{eV})$ but with a high activation barrier $\left(E_{\mathrm{a}}=1.85 \mathrm{eV}\right)$ (process 4a, Table 2).

Coverage effects are crucial in $\mathrm{HCl}$ oxidation [48] and thus are likely to be important also under oxychlorination conditions. Under high $\mathrm{Cl}$ coverage conditions, EDC formation from direct chlorination of $\mathrm{ClCH}_{2} \mathrm{CH}_{2}^{*}$ (process $4 \mathrm{~b}^{\dagger}$, Table 2) yielded results more consistent with experimental observation; no activation barrier was observed for this process (thus it would be controlled by the $\mathrm{Cl}$ diffusion on the surface), and an exothermic reaction energy was determined $(\Delta E=-0.87 \mathrm{eV})$. Under these conditions the $\mathrm{ClCH}_{2} \mathrm{CH}_{2}^{*}$ intermediate is destabilised by $1.42 \mathrm{eV}$, which is offset by the dissociative adsorption of $\mathrm{HCl}(-1.79 \mathrm{eV})$. In other words, the high coverage responsible for the induced destabilisation is a direct consequence of a high degree of $\mathrm{HCl}$ dissociative adsorption. Hence, $\mathrm{HCl}$ dissociation and the induced distortion are directly coupled with a net exothermic energy balance. Desorption of EDC is endothermic by $0.71 \mathrm{eV}$ (process 15 , Table 2).

The competing oxidation route, the oxametallacycle intermediate (OMME) formed by the addition of coadsorbed $\mathrm{O}$ to $\mathrm{C}_{2} \mathrm{H}_{4}$ (process 5 , Table 2 ), can undergo a variety of processes. Formation of acetaldehyde (by $1,2-\mathrm{H}$ shift, process 6 , Table 2 ) is a possibility, as discussed in previous works [69]. Acetaldehyde formation is exothermic by $-0.88 \mathrm{eV}$ and has an activation barrier of $E_{\mathrm{a}}=1.22$ $\mathrm{eV}$; desorption of acetaldehyde is endothermic by $0.90 \mathrm{eV}$ (process A5, Table 2). Under thermodynamic control, it is likely that this species will ultimately undergo combustion to $\mathrm{CO}_{2}$ and $\mathrm{H}_{2} \mathrm{O}$. It is found that cleavage of the $\mathrm{C}-\mathrm{C}$ bond in OMME, resulting in fragmentation, has a lower activation barrier of $1.06 \mathrm{eV}$, making this the more feasible route (process 7 , Table 2 ). The fragmentation yields formaldehyde and a $\mathrm{CH}_{2}^{*}$ species bound to the surface. The $\mathrm{CH}_{2}^{*}$ fragment can then react with coadsorbed $\mathrm{O}$ to generate a second equivalent of formaldehyde (process 8 , Table 2); this step is highly exothermic $(\Delta E=-1.30 \mathrm{eV})$ and has a negligible activation barrier $\left(E_{\mathrm{a}}=0.02 \mathrm{eV}\right)$ owing to the instability of the $\mathrm{CH}_{2}^{*}$ fragment. Subsequently, formaldehyde can re-adsorb to the surface, forming an intermediate bridging the coordinatively unsaturated Ru site $\left(\mathrm{Ru}_{\text {cus }}\right)$ and another $\mathrm{O}_{\text {cus }}$, adding across the $\mathrm{C}=\mathrm{O}$ carbonyl bond in the process (process 9 , Table 2). The formation of the bridging intermediate is exothermic $(\Delta E=-0.89 \mathrm{eV})$ and was determined to have a negligible activation barrier. $\mathrm{CO}_{2}$ is then generated by two consecutive $\mathrm{H}$ abstractions from the intermediate. The first $\mathrm{H}$ abstraction (process 10, Table 2) is highly exothermic $(\Delta E=-2.30 \mathrm{eV})$ and has a low activation barrier $\left(E_{\mathrm{a}}=0.54 \mathrm{eV}\right)$. The second $\mathrm{H}$ abstraction (process 11a, Table 2), on the other hand, was determined to have a high activation barrier of $1.70 \mathrm{eV}$ and was found to be thermoneutral $(\Delta E=-0.04 \mathrm{eV})$ under the low coverage model applied. Further calculations using a high $\mathrm{Cl}$ coverage model (process $11 \mathrm{~b}^{\dagger}$, Table 2) yielded a much more exothermic reaction energy $(\Delta E=-2.09 \mathrm{eV})$, and a negligible activation barrier. The intermediate was calculated to have been destabilised by $1.66 \mathrm{eV}$, again this energy can be compensated for by the exothermicity of $\mathrm{HCl}$ dissociative adsorption. Desorption of $\mathrm{CO}_{2}$ is endothermic by $0.20 \mathrm{eV}$ (process A6, Table 2). Finally, the $\mathrm{H}$ abstracted from the intermediates by vicinal $\mathrm{O}_{\mathrm{b}}$ will ultimately be transferred to coadsorbed $\mathrm{O}_{\text {cus, }}$, thus evolving water and preserving the surface $\mathrm{O}_{\mathrm{b}}$ atoms, as in the case of the Deacon reaction (processes V, VI and VII, Table 2).

Since VCM, like $\mathrm{C}_{2} \mathrm{H}_{4}$, possesses a $\mathrm{C}=\mathrm{C}$ bond, the same processes (both chlorination and oxidation) that apply to $\mathrm{C}_{2} \mathrm{H}_{4}$ may also apply to VCM, at least in theory, resulting potentially in products containing both $\mathrm{O}$ and $\mathrm{Cl}$. Several pathways were investigated. Addition of either $\mathrm{Cl}$ or $\mathrm{O}$ across the $\mathrm{C}=\mathrm{C}$ results in two possible intermediates, since there are two approach trajectories (as opposed to only one for $\mathrm{C}_{2} \mathrm{H}_{4}$, owing to the fact that in the latter molecule the two $\mathrm{C}$ atoms are equivalent). Considering first VCM chlorination, it is noted that there are two possibilities arising from $\mathrm{Cl}$ addition to VCM; either a vicinal dichloride $\left(\mathrm{ClCH}_{2} \mathrm{ClCH}^{*}\right)$ or a geminal dichloride $\left(\mathrm{Cl}_{2} \mathrm{CHCH}_{2}^{*}\right)$. Formation of the geminal dichloride (process 16, Table 2) is endothermic by $0.72 \mathrm{eV}$ and has an activation barrier of $0.99 \mathrm{eV}$. The $\mathrm{Cl}_{2} \mathrm{CHCH}_{2}^{*}$ intermediate can then either gain $\mathrm{H}$ from $\mathrm{O}_{\mathrm{b}} \mathrm{H}$, originating from $\mathrm{HCl}$ dissociative adsorption, yielding $\mathrm{CH}_{3} \mathrm{CHCl}_{2}\left(\Delta E=0.25 \mathrm{eV}, E_{\mathrm{a}}=0.99 \mathrm{eV}\right.$, process 17 , Table 2), or alternatively $\mathrm{O}_{\mathrm{b}}$ can abstract $\mathrm{H}$ from the intermediate to give an unsaturated product, $\mathrm{CH}_{2} \mathrm{CCl}_{2}\left(\Delta E=-0.25 \mathrm{eV}, E_{\mathrm{a}}=1.39\right.$ $\mathrm{eV}$, process 18, Table 2). Both $\mathrm{CH}_{3} \mathrm{CHCl}_{2}$ and $\mathrm{CH}_{2} \mathrm{CCl}_{2}$ have similar adsorption energies $(-0.53 \mathrm{eV}$ and $-0.54 \mathrm{eV}$, processes $\mathrm{A} 9$ and A10 respectively, Table 2). Formation of the vicinal dichloride is endothermic by $0.56 \mathrm{eV}$ and has an activation barrier of $1.09 \mathrm{eV}$ (process 12, Table 2). As with the geminal dichloride intermediate, potential products can be evolved by either gaining $\mathrm{H}$ from $\mathrm{O}_{\mathrm{b}}$, or by $\mathrm{H}$ abstraction by $\mathrm{O}_{\mathrm{b}}$. Addition of $\mathrm{H}$ leads to an alternative route to obtain $\operatorname{EDC}\left(\Delta E=0.47 \mathrm{eV}, E_{\mathrm{a}}=1.18 \mathrm{eV}\right.$, process 13 , Table 2). $\mathrm{H}$ abstraction can yield two unsaturated products, $Z-\mathrm{C}_{2} \mathrm{H}_{2} \mathrm{Cl}_{2}$ and $\mathrm{E}-$ $\mathrm{C}_{2} \mathrm{H}_{2} \mathrm{Cl}_{2}$, which form a pair of geometrical isomers depending on the conformation of the intermediate. The reaction energies for the two processes are very similar $(\Delta E=-0.16 \mathrm{eV}, \Delta E=-0.15$ $\mathrm{eV}$, for $\mathrm{Z}-\mathrm{C}_{2} \mathrm{H}_{2} \mathrm{Cl}_{2}$ and $\mathrm{E}-\mathrm{C}_{2} \mathrm{H}_{2} \mathrm{Cl}_{2}$ respectively, processes 14 and 15 , Table 2). However the activation barrier for the formation of $\mathrm{Z}-\mathrm{C}_{2} \mathrm{H}_{2} \mathrm{Cl}_{2}$ is significantly higher than that of $\mathrm{E}-\mathrm{C}_{2} \mathrm{H}_{2} \mathrm{Cl}_{2}\left(E_{\mathrm{a}}=1.37\right.$ $\mathrm{eV}$, c.f. $E_{\mathrm{a}}=0.97 \mathrm{eV}$ ), likely due to steric repulsion between $\mathrm{Cl}$ on the same side of the molecule in the case of $\mathrm{Z}-\mathrm{C}_{2} \mathrm{H}_{2} \mathrm{Cl}_{2}$. Additionally, the $\mathrm{E}_{-} \mathrm{C}_{2} \mathrm{H}_{2} \mathrm{Cl}_{2}$ desorption energy is more endothermic at $0.53 \mathrm{eV}$ (process A8, Table 2) compared to $0.32 \mathrm{eV}$ for $\mathrm{Z}-\mathrm{C}_{2} \mathrm{H}_{2} \mathrm{Cl}_{2}$ (process A7, Table 2). Indeed, it is possible that the unsaturated products from VCM chlorination could in turn undergo further reaction in an analogous manner. However, since all the reaction energies associated with the formation of VCM chlorination products are endothermic, and all of these processes have high activation barriers, further reactions beyond this point have not been examined.

Turning to VCM oxidation, similarly two distinct intermediates can be formed, $\mathrm{CH}_{2} \mathrm{CHClO}^{* *}\left(\Delta E=-0.27 \mathrm{eV}, E_{\mathrm{a}}=0.73 \mathrm{eV}\right.$, process 21, Table 2), and $\mathrm{OCH}_{2} \mathrm{CHCl}^{* *}\left(\Delta E=-0.04 \mathrm{eV}, E_{\mathrm{a}}=0.98 \mathrm{eV}\right.$, process 19 , Table 2), depending on the side of the VCM molecule from which $\mathrm{O}$ approaches. As with OMME, $\mathrm{H}$ transfer can yield an aldehyde, $\mathrm{CH}_{2} \mathrm{ClCHO}$, from $\mathrm{OCH}_{2} \mathrm{CHCl}^{* *}\left(\Delta E=-1.05 \mathrm{eV}, E_{\mathrm{a}}=1.10 \mathrm{eV}\right.$, process 20, Table 2), and in the case of $\mathrm{CH}_{2} \mathrm{CHCl}^{* *}$ an acid chloride, $\mathrm{CH}_{3} \mathrm{COCl}$, is formed $\left(\Delta E=-1.23 \mathrm{eV}, E_{\mathrm{a}}=1.19 \mathrm{eV}\right.$, process 22 , Table 2). Desorption of the aldehyde is considerably more endothermic at $1.13 \mathrm{eV}$ (process A11, Table 2), compared to 0.72 $\mathrm{eV}$ for the acid chloride (process A12, Table 2).

\section{Discussion}

\subsection{Origin of selectivity}

Selectivity between oxidation and chlorination of $\mathrm{C}_{2} \mathrm{H}_{4}$ is governed by the interplay between thermodynamic and kinetic factors. Thermodynamic selectivity can originate from differing adsorption energies between species. Products with highly exothermic adsorption energies are more likely to undergo further reaction than to be desorbed as an observed product, thus dictating selectivity [70].

Fig. 3 depicts the adsorption energies for a variety of chlorination products as well as $\mathrm{C}_{2} \mathrm{H}_{4}$ as a function of surface coverage 


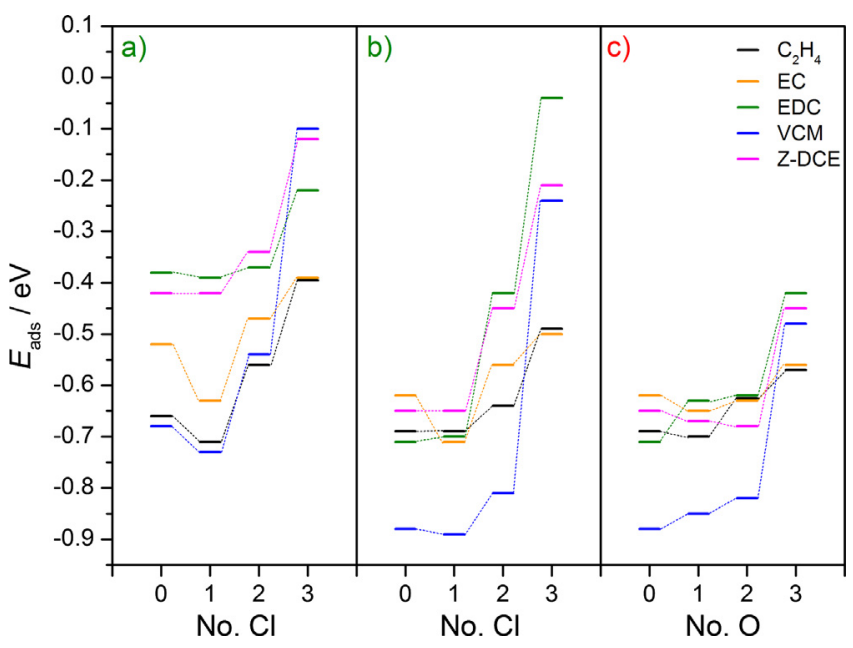

Fig. 3. Adsorption energies of ethylene, EC, EDC, VCM, and Z-DCE for a variety of surface compositions. (a) Adsorption energy as a function of $\mathrm{Cl}$ coverage on the $\mathrm{RuO}_{2}$ surface where half of the bridging oxygen atoms were replaced with $\mathrm{Cl}$. (b) Adsorption energy as a function of $\mathrm{Cl}$ coverage. (c) Adsorption energy as a function of $O$ coverage.

(by $\mathrm{O}$ or $\mathrm{Cl}$ ). In general, higher coverages lead to destabilised adsorbed species. It is notable that VCM is more strongly adsorbed than other species at all but the highest of coverages, owing to its compact size and its ability to interact with Ru active sites through either $\mathrm{Cl}$ or the $\mathrm{C}=\mathrm{C}$ bond, or indeed both (occupying two active sites) at lower coverages. Therefore, if formed, VCM is likely to stay on the surface, as it is the most stable product at low coverages. It is also important to note that the $\mathrm{C}_{2} \mathrm{H}_{4}$ adsorption energy remains relatively unchanged at high $\mathrm{O}$ coverage, compared to the adsorption energy for a clean surface. Since $\mathrm{C}_{2} \mathrm{H}_{4}$ is the precursor for combustion products, the stronger $\mathrm{C}_{2} \mathrm{H}_{4}$ adsorption further supports oxidation to $\mathrm{CO}_{2}$ and $\mathrm{H}_{2} \mathrm{O}$. However, at high coverages, VCM shows a lower adsorption energy than $\mathrm{C}_{2} \mathrm{H}_{4}$, thus favouring the thermodynamic selectivity. This phenomena has been reported for the gold-catalysed selective hydrogenation of $\mathrm{C}-\mathrm{C}$ triple bonds in alkynes, to the exclusion of hydrogenation of $\mathrm{C}=\mathrm{C}$ bonds in the resulting alkenes, since competitive adsorption between the reactants and products ensure that the products do not undergo further reaction, being displaced in favour of the adsorption of the reactant [69]. The lower adsorption energy for VCM compared to $\mathrm{C}_{2} \mathrm{H}_{4}$ means that under high coverage conditions, the two species compete for the remaining adsorption sites, with $\mathrm{C}_{2} \mathrm{H}_{4}$ being preferentially adsorbed. Consequently, VCM desorbs from the catalyst surface once it is generated in favour of adsorption of $\mathrm{C}_{2} \mathrm{H}_{4}$, rather than undergoing further reaction and thus leading to an enhanced selectivity.

As for the kinetic aspects of the reaction, the first step in the reaction is crucial, i.e. whether chlorination (process 1 ) or oxidation (process 5) of $\mathrm{C}_{2} \mathrm{H}_{4}$ takes place. The activation barrier for addition of $\mathrm{Cl}$ to $\mathrm{C}_{2} \mathrm{H}_{4}$ is lower than for the addition of $\mathrm{O}$, however the chlorination process is endothermic compared to the exothermic oxidation route. Whilst it is very likely that the initial and final states for $\mathrm{Cl}$ addition to $\mathrm{C}_{2} \mathrm{H}_{4}$ exist in equilibrium, the higher activation barrier for oxidation cannot be breached. Thus, at lower temperatures, the system is more prone to kinetic control and only chlorinated products are observed, as the intermediate $\mathrm{C}_{2} \mathrm{H}_{4} \mathrm{Cl}^{*}$ is consumed to form chlorinated products over time. On the other hand, at higher temperatures, thermodynamic control prevails, and since the oxidation process is much more exothermic, it is more likely that the formation of OMME is irreversible, and hence at higher temperatures more combustion products are observed to the exclusion of chlorination products.

Fig. 4 depicts the reaction profile for the oxidation and chlorination of $\mathrm{C}_{2} \mathrm{H}_{4}$, with chlorination progressing ultimately to EDC formation, at high and low $\mathrm{Cl}$ coverage. At low coverage, the activation barrier towards EDC is prohibitively high, whereas at high $\mathrm{Cl}$ coverage (process $4 \mathrm{~b}$, Table 2 ), the same process yielded results more consistent with experimental observation. It was calculated that the $\mathrm{ClCH}_{2} \mathrm{CH}_{2}^{*}$ intermediate is destabilised by $1.42 \mathrm{eV}$, which can be easily offset by the dissociative adsorption of $\mathrm{HCl}$ $(-1.79 \mathrm{eV})$. At high $\mathrm{Cl}$ coverage, however, adsorbed species are somewhat destabilised by the coadsorbed chlorine atoms, thus diminishing the activation barrier of the processes as the energetic gap is closed between the initial and transition states of each a)

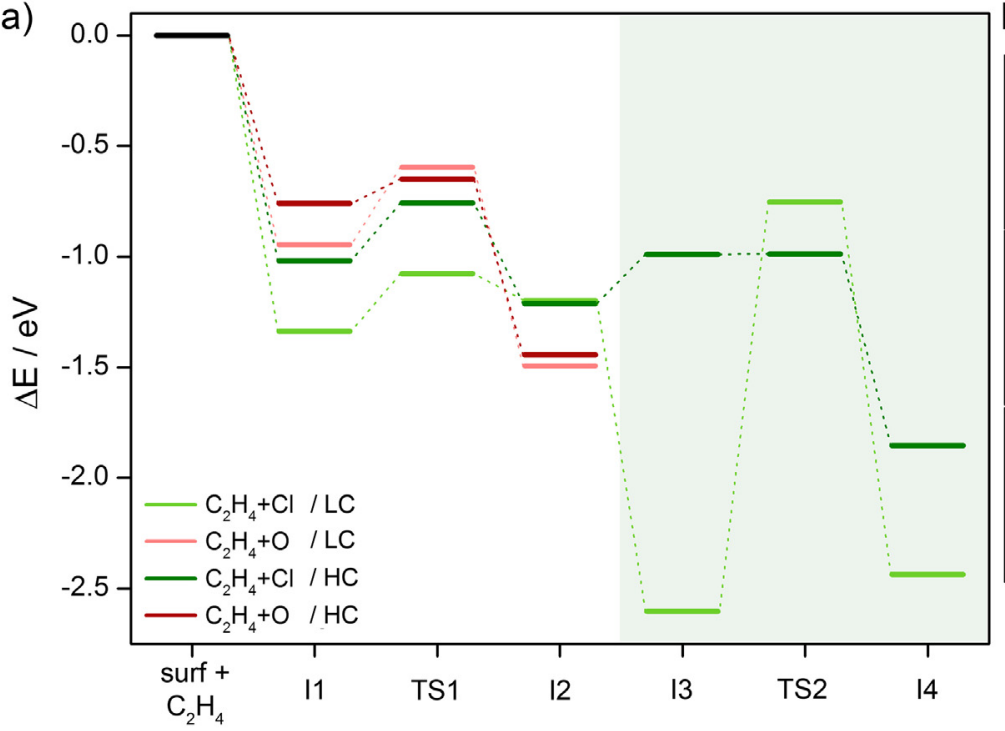

b)

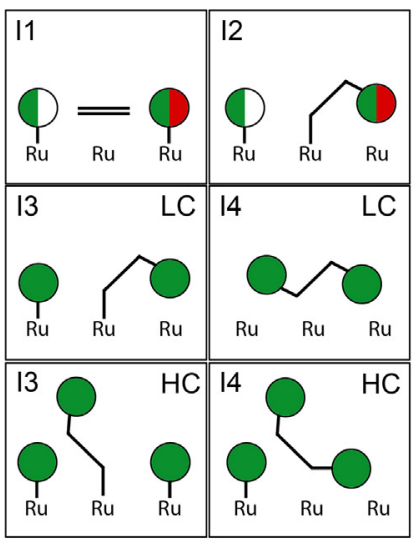

Fig. 4. (a) Reaction profiles for oxidation and chlorination of $\mathrm{C}_{2} \mathrm{H}_{4}$ at low (LC) and high (HC) chlorine coverage. The chlorination route depicts the eventual formation of EDC. The white background region indicates where the oxidation and chlorination processes compete at the specific coverage, whilst the green background region indicates that additional $\mathrm{HCl}$ has been dissociatively adsorbed to allow the reaction to continue to the formation of EDC, at high and low $\mathrm{Cl}$ coverages. (b) Diagrams depicting the considered configurations, where green circles indicate chlorine atoms, green/white circles indicate either a chlorine or no atom, and green/red circles indicate either chlorine or oxygen atoms. 
process. This is reflected in differences in the atomic distances at high $\mathrm{Cl}$ coverage compared to low $\mathrm{Cl}$ coverage. At low $\mathrm{Cl}$ coverage, the distance between a $\mathrm{Cl}$ atom and the $\mathrm{C}$ atom of a coadsorbed $\mathrm{C}_{2-}$ $\mathrm{H}_{5} \mathrm{Cl}^{*}$ intermediate (Table 2, process 4a Fig. 5b) is $3.53 \AA$. However, at high coverage (Table 2 , process $4 \mathrm{~b} \dagger$ ), the corresponding distance is only $3.08 \AA$, reflecting the crowding on the surface responsible for the destabilisation of the $\mathrm{C}_{2} \mathrm{H}_{5} \mathrm{Cl}^{*}$ intermediate. It is also notable that whilst the activation barrier for $\mathrm{C}_{2} \mathrm{H}_{4}$ chlorination is lower than that of oxidation under low coverage conditions, at high coverages the pattern is reversed and the activation barriers are comparable. This implies that at high coverage, the competition between oxidation and chlorination of $\mathrm{C}_{2} \mathrm{H}_{4}$ is enhanced, leading to reduced selectivity.

Under kinetic control, it is important to consider why EDC, and not $\mathrm{C}_{2} \mathrm{H}_{5} \mathrm{Cl}$ or VCM, is produced. The key to this again is the surface coverage, which can confine and destabilise intermediates. For EDC generation under high $\mathrm{Cl}$ coverage, the additional coadsorbed $\mathrm{Cl}$ destabilises the $\mathrm{C}_{2} \mathrm{H}_{4} \mathrm{Cl}^{*}$ intermediate, with the destabilisation being compensated for by the exothermicity of $\mathrm{HCl}$ dissociative adsorption. Hence, the energetic barrier between the intermediate and the transition state is eliminated by the destabilisation of the intermediate. Formation of EDC takes place via the intermediate reacting with one of the adjacent coadsorbed $\mathrm{Cl}$, thus relieving the species of its confinement, and as such, the process is highly exothermic. On the other hand, gaining (losing) $\mathrm{H}$ from (to) $\mathrm{O}_{\mathrm{b}} \mathrm{H}$ $\left(\mathrm{O}_{\mathrm{b}}\right)$ to generate $\mathrm{C}_{2} \mathrm{H}_{5} \mathrm{Cl}(\mathrm{VCM})$ does not involve the coadsorbed $\mathrm{Cl}$ responsible for the destabilisation and hence, the confinement is not relieved, therefore rendering it very likely that the thermodynamics and kinetics of these processes at high coverage would be largely unchanged from their low coverage values. As such, the experimental observation that the main chlorination product is EDC, rather than VCM, is justified theoretically.

Previous studies [44] suggest that EDC dehydrochlorination, generating VCM and $\mathrm{HCl}$, requires sufficiently acidic sites on the catalyst surface, which $\mathrm{RuO}_{2}\left(\begin{array}{lll}1 & 1 & 0\end{array}\right)$ lacks, hence in situ dehydrochlorination does not occur and VCM is not a major product. Furthermore, it was suggested that at high partial $\mathrm{HCl}$ pressures, a significant proportion of $\mathrm{O}_{\mathrm{b}}$ atoms are replaced by $\mathrm{Cl}$, thus limiting the number of $\mathrm{O}_{b}$ sites able to abstract hydrogen from intermediates, or indeed provide hydrogen to intermediates having deprotonated $\mathrm{HCl}$ during dissociative adsorption [37]. This would also hinder any processes that require such sites, thus further favouring the generation of EDC which does not depend on $\mathrm{H}$ transfers to or from $\mathrm{O}_{\mathrm{b}}$. Under thermodynamic control, it is evident that oxidation dominates, and it is clear why combustion to $\mathrm{CO}_{2}$ is preferred over intramolecular formation of $\mathrm{CH}_{3} \mathrm{CHO}$. The activation barrier for fragmentation of OMME to $\mathrm{CH}_{2}^{*}$ and $\mathrm{H}_{2} \mathrm{CO}$ is consider- ably lower than that of the alternative $\mathrm{H}$ transfer processes. Additionally, all of the subsequent steps under low coverage (except for the final $\mathrm{H}$ abstraction) are strongly exothermic and possess either small or negligible activation barriers.

\subsection{Requirements for a good VCM catalyst}

From the description above, we have identified three main requirements needed for a successful ethylene-to-VCM catalyst. Firstly, we consider the thermodynamic term. The adsorption energy for ethylene must fall in the same range as at least one of the other reactants (fulfilled by $\mathrm{O}_{2}$ in this case). Moreover, it has to be more strongly bound than the desired product. For $\mathrm{RuO}_{2}$, this is only achieved for high coverages where the bonding energy of VCM is lower than that of ethylene. Hence, competition for active sites on the catalyst surface between adsorbates means that VCM is displaced in preference of $\mathrm{C}_{2} \mathrm{H}_{4}$, limiting the extent to which VCM undergoes subsequent reactions. These persistent active oxygen atoms are a severe threat to the production of VCM. The $\mathrm{C}-\mathrm{O}$ bond is stronger than the $\mathrm{C}-\mathrm{Cl}$ bond ( 3.71 vs. $3.39 \mathrm{eV}$ ). This is an indication for the calculated effect that chlorination is reversible on the surface, whilst $\mathrm{C}-\mathrm{O}$ formation is exothermic and thus irreversible. Energetically, this restriction implies that oxygen cannot diffuse across $\mathrm{Ru}_{\text {cus }}$ positions close to adsorbed ethylene. Secondly, the geometry of the ( 110$)$ surface poses also the additional problem of dimensional confinement, shared by the other lowest energy surfaces: ( $\left.\begin{array}{lll}1 & 0 & 1\end{array}\right)$ and $\left(\begin{array}{lll}0 & 0 & 1\end{array}\right)$ [71]. Transport of the active $\mathrm{Cl}$ and $\mathrm{O}$ atoms takes place only along the $\left[\begin{array}{lll}0 & 0 & 1\end{array}\right] \mathrm{Ru}_{\text {cus }}$ direction. This implies that once ethylene is adsorbed, the first atom in the neighbouring sites is the first one to be incorporated on the surface. As chlorination is reversible, the presence of a single $\mathrm{O}$ atom in the neighbouring site precipitates the production of $\mathrm{CO}_{2}$. Therefore, confined transport along a single direction is detrimental to the formation of VCM, with the constrained diffusion of ethylene across the surface limiting the number of coadsorbed species it can react with, making it more difficult for the kinetically preferred chlorination to occur.

The final point concerns the effective abstraction of the $\mathrm{H}$ atoms from the chlorinated fragments or even EDC. Basic sites are needed for stripping $\mathrm{H}$ atoms from the intermediates leading to VCM. As the presence of $\mathrm{O}_{\text {cus }}$ limits selectivity by favouring combustion, the basicity of the geometrically reachable $\mathrm{O}_{\mathrm{b}}$ needs to be strong enough to allow effective $\mathrm{H}$ abstraction. On the $\mathrm{RuO}_{2}$ surface, $\mathrm{HCl}-\mathrm{O}_{2}$ mixtures produce surfaces where $\mathrm{O}_{\mathrm{b}}$ are partially replaced by $\mathrm{Cl}$ atoms ( $\sim 50 \%$ replacement) [56]. Whilst this limit is crucial to ensure the stability of the catalyst under Deacon conditions, it impedes an effective dehydrogenation of the intermediates, most a)

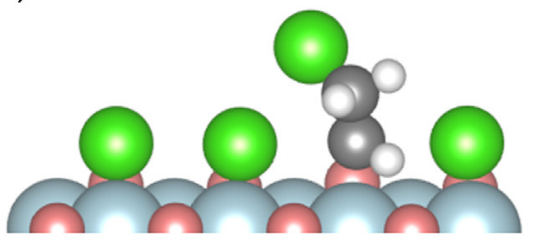

c)

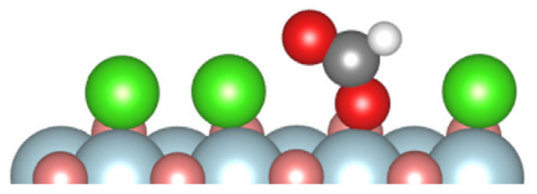

b)

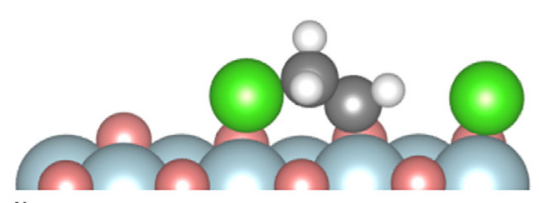

d)

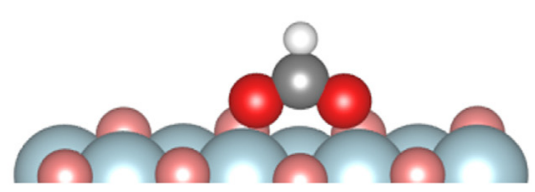

Fig. 5. (a) Side view of the optimised geometry of $\mathrm{C}_{2} \mathrm{H}_{4} \mathrm{Cl}^{*}$ at high coverage. (b) $\mathrm{C}_{2} \mathrm{H}_{4} \mathrm{Cl}^{*}$ under low $\mathrm{Cl}$ coverage. (c) $\mathrm{CHO}_{2}^{*}$ under high $\mathrm{Cl}$ coverage. (d) $\mathrm{CHO} \mathrm{O}_{2}^{*}$ under low $\mathrm{Cl}$ coverage. Colour legend: blue $(\mathrm{Ru})$, pale red (surface $\mathrm{O})$, bright red (adsorbed $\mathrm{O})$, green $(\mathrm{Cl})$, dark grey $(\mathrm{C})$, and light grey $(\mathrm{H})$. 
likely leading to enhanced EDC production. Therefore, a successful VCM catalyst needs to maintain effective $O$ centres able to strip hydrogen from the intermediates.

Additionally, in order to further validate our approach, we set up a microkinetic model. The model is built on our previous results on Deacon reaction [49] and thus is only briefly commented on here. Notice that since the surface presents strong anisotropy and monodimensional character [59], mean-field approaches can be biased and thus they can only be taken as qualitative. Still, the reaction order for $\mathrm{HCl}$ in the Deacon is found to be 0.3 , in reasonable agreement with the experimental values. In contrast, the reaction orders of $\mathrm{HCl}$ for EDC and VCM production over $\mathrm{RuO}_{2}$ are 0.89 and -0.14 , respectively. Thus, ethylene oxychlorination to EDC shows a remarkable difference compared to the Deacon reaction, in terms of the dependence on $\mathrm{HCl}$. The kinetic similarities between reaction orders close to zero for $\mathrm{Cl}_{2}$ and VCM can also represent a challenge in improving $\mathrm{VCM}$ production on $\mathrm{RuO}_{2}$. Finally, it is noted that the production of $\mathrm{Cl}_{2}$ was negligible under the conditions at which EDC was observed, in excellent agreement with experiments.

\section{Conclusions}

Under the conditions required for catalytic oxychlorination of ethylene over $\mathrm{RuO}_{2}\left(\begin{array}{ll}1 & 10\end{array}\right)$, a variety of chemical reactions are possible, with competing oxidation and chlorination processes. Whilst oxidation, and ultimately combustion to $\mathrm{CO}_{2}$ and $\mathrm{H}_{2} \mathrm{O}$, is favoured thermodynamically, conversion to the desired oxychlorination products is possible at lower temperatures through kinetic control. The coverage and composition of the surface is crucial to the behaviour of the system. Under high $\mathrm{Cl}$ coverages, competitive adsorption between $\mathrm{C}_{2} \mathrm{H}_{4}$ and VCM ensures that VCM is displaced by $\mathrm{C}_{2} \mathrm{H}_{4}$, owing to its less exothermic adsorption energy, preventing the excessive formation of products derived from VCM. The effect of dimensional confinement of $\mathrm{C}_{2} \mathrm{H}_{4}$ means that coadsorbed species react on a "first-come, first-served" basis, thus resulting in a potentially considerable degree of combustion where coadsorbed $\mathrm{O}$ is involved. The effect of substitution of bridging $\mathrm{O}$ sites by $\mathrm{Cl}$, is key to understanding the prevalence of EDC over VCM under kinetic control, since the $\mathrm{O}_{\mathrm{b}}$ sites required to abstract $\mathrm{H}$ from intermediates are essential to VCM formation. Therefore, the surface composition of the catalyst has a major impact on activity and selectivity and is an important consideration in the development of new catalysts. It is intended that this study will inform future work in developing highly selective, robust and active catalysts for ethylene oxychlorination, defining the basic requirements for a good catalyst by offering mechanistic insights at the molecular level.

\section{Acknowledgments}

Financial support from the Swiss National Science Foundation (Project No. 200021-156107), the ICIQ Foundation, and the Spanish MINECO (CTQ2015-68770-R) is acknowledged. M.C.-C. also acknowledges MINECO for a "Juan de la Cierva-Formación" fellowship (FJCI-2014-20568).

\section{Appendix A. Supplementary material}

\section{References}

[1] J. Wang, C.Y. Fan, K. Jacobi, G. Ertl, The kinetics of $\mathrm{CO}$ oxidation on $\mathrm{RuO}_{2}(110)$ : bridging the pressure gap, J. Phys. Chem. B 106 (2002) 3422-3427.
[2] H. Over, Y.D. Kim, A.P. Seitsonen, S. Wendt, E. Lundgren, M. Schmid, P. Varga, A. Morgante, G. Ertl, Atomic-scale structure and catalytic reactivity of the $\mathrm{RuO}_{2}(110)$ surface, Science 287 (2000) 1474-1476.

[3] H. Over, A.P. Seitsonen, E. Lundgren, M. Schmid, P. Varga, Direct imaging of catalytically important processes in the oxidation of $\mathrm{CO}$ over $\mathrm{RuO}_{2}(100)$, J. Am. Chem. Soc. 123 (2001) 11807-11808.

[4] Y. Wang, K. Jacobi, W.-D. Schöne, G. Ertl, Catalytic oxidation of ammonia on $\mathrm{RuO}_{2}(110)$ surfaces: mechanism and selectivity, J. Phys. Chem. B 109 (2005) 7883-7893

[5] B.-Z. Zhan, M.A. White, T.-K. Sham, J.A. Pincock, R.J. Doucet, K.V.R. Rao, K.N. Robertson, T.S. Cameron, Zeolite-confined nano- $\mathrm{RuO}_{2}$ : a green, selective, and efficient catalyst for aerobic alcohol oxidation, J. Am. Chem. Soc. 125 (2003) 2195-2199.

[6] Z. Liu, V. Sriram, J.-Y. Lee, Heterogeneous oxidation of elemental mercury vapor over $\mathrm{RuO}_{2} /$ rutile $\mathrm{TiO}_{2}$ catalyst for mercury emissions control, Appl. Catal. B Environ. 207 (2017) 143-152.

[7] A.S. Fajardo, H.F. Seca, R.C. Martins, V.N. Corceiro, I.F. Freitas, M.E. QuintaFerreira, R.M. Quinta-Ferreira, Electrochemical oxidation of phenolic wastewaters using a batch-stirred reactor with $\mathrm{NaCl}$ electrolyte and $\mathrm{Ti} / \mathrm{RuO}_{2}$ anodes, J. Electroanal. Chem. 785 (2017) 180-189.

[8] Y.-H. Fang, Z.-P. Liu, Mechanism and Tafel lines of electro-oxidation of water to oxygen on $\mathrm{RuO}_{2}(110)$, J. Am. Chem. Soc. 132 (2010) 18214-18222.

[9] H. Over, Surface chemistry of ruthenium dioxide in heterogeneous catalysis and electrocatalysis: from fundamental to applied research, Chem. Rev. 112 (2012) 3356-3426.

[10] K.S. Exner, J. Anton, T. Jacob, H. Over, Controlling selectivity in the chlorine evolution reaction over $\mathrm{RuO}_{2}$-based catalysts, Angew. Chem. Int. Ed. 53 (2014) $11032-11035$

[11] K. Iwanaga, K. Seki, T. Hibi, K. Issoh, T. Suzuta, M. Nakada, Y. Mori, T. Abe, The development of improved hydrogen chloride oxidation process, Sumitomo Kagaku. (2004) 1-11.

[12] K. Seki, Development of $\mathrm{RuO}_{2} /$ Rutile- $\mathrm{TiO}_{2}$ catalyst for industrial $\mathrm{HCl}$ oxidation process, Catal. Surv. Asia. 14 (2010) 168-175.

[13] J. Pérez-Ramírez, C. Mondelli, T. Schmidt, O.F.-K. Schlüter, A. Wolf, L. Mleczko, T. Dreier, Sustainable chlorine recycling via catalysed $\mathrm{HCl}$ oxidation: from fundamentals to implementation, Energy Environ. Sci. 4 (2011) 4786-4799.

[14] A. Wolf, L. Mleczko, O.F.-K. Schlüter, S. Schubert, Method for producing chlorine by gas phase oxidation, EP2026905 A1, 2007.

[15] H.A. Hansen, I.C. Man, F. Studt, F. Abild-Pedersen, T. Bligaard, J. Rossmeisl, Electrochemical chlorine evolution at rutile oxide (110) surfaces, Phys. Chem. Chem. Phys. 12 (2010) 283-290.

[16] F. Studt, F. Abild-Pedersen, H.A. Hansen, I.C. Man, J. Rossmeisl, T. Bligaard, Volcano relation for the Deacon process over transition-metal oxides, ChemCatChem. 2 (2010) 98-102.

[17] S. Trasatti, Physical electrochemistry of ceramic oxides, Electrochim. Acta 36 (1991) 225-241.

[18] S. Trasatti, Electrocatalysis: understanding the success of DSA ${ }^{\circledR}$, Electrochim. Acta. 45 (2000) 2377-2385.

[19] N. López, G. Novell-Leruth, Rules for selectivity in oxidation processes on $\mathrm{RuO}_{2}$ (110), Phys. Chem. Chem. Phys. 12 (2010) 12217-12222.

[20] Businesswire, Global polyvinyl chloride (PVC) market worth USD 72.330 billion by 2021 - Analysis, Technologies \& Forecasts Report 2016-2021 Vendors: INOVYN, Axiall Corp, Westlake Chemical Corp - Research and Markets, 2016.

[21] G.J. Hutchings, Vapor phase hydrochlorination of acetylene: correlation of catalytic activity of supported metal chloride catalysts, J. Catal. 96 (1985) 292 295.

[22] P. Johnston, N. Carthey, G.J. Hutchings, Discovery, development, and commercialization of gold catalysts for acetylene hydrochlorination, J. Am. Chem. Soc. 137 (2015) 14548-14557.

[23] K. Weissermel, H.-J. Arpe, Vinyl-halogen and Vinyl-oxygen Compounds, in: Ind. Org. Chem, Wiley-VCH, Weinheim, 2008, pp. 217-238.

[24] J.S. Naworski, E.S. Velez, Oxychlorination of ethylene, in: B. Leach (Ed.), Appl. Ind. Catal., Academic Press, 1983, pp. 239-273.

[25] M. Malentacchi, C. Rubini, Oxychlorierungsatalysatorzusammensetzung zur Regelung von exothermischen Reaktionen in einem Festbett, EP1020222 B1, 2004.

[26] N.B. Muddada, T. Fuglerud, C. Lamberti, U. Olsbye, Tuning the activity and selectivity of $\mathrm{CuCl}_{2} / \gamma-\mathrm{Al}_{2} \mathrm{O}_{3}$ ethene oxychlorination catalyst by selective promotion, Top. Catal. 57 (2014) 741-756.

[27] N.B. Muddada, U. Olsbye, L. Caccialupi, F. Cavani, G. Leofanti, D. Gianolio, S. Bordiga, C. Lamberti, Influence of additives in defining the active phase of the ethylene oxychlorination catalyst, Phys. Chem. Chem. Phys. 12 (2010) 56055618.

[28] J.P. Henley, M.E. Jones, D.A. Hickman, K.A. Marshall, D.J. Reed, W.D. Clarke, M. M. Olken, L.E. Walko, Process for vinyl chloride manufacture from ethane and ethylene with partial $\mathrm{HCl}$ recovery from reactor effluent, US 6933417 B1, 2005.

[29] F.E. Van Rooijen, J. Johan, A. De Bruijn, Catalytic oxychlorination, US 0054708 A1, 2009.

[30] M. Loos, J. Goulon, M. Bertucci, R. Bachelard, Structural studies using X.A.S. of the active species catalysing the oxychlorination of ethylene - II, Phys. B Condens. Matter. 158 (1989) 188-190.

[31] C. Lamberti, C. Prestipino, F. Bonino, L. Capello, S. Bordiga, G. Spoto, A. Zecchina, S. Diaz Moreno, B. Cremaschi, M. Garilli, A. Marsella, D. Carmello, S. Vidotto, G. Leofanti, The chemistry of the oxychlorination catalyst: an In Situ, time-resolved XANES study, Angew. Chem. Int. Ed. 41 (2002) 2341-2344. 
[32] D. Carmello, E. Finocchio, A. Marsella, B. Cremaschi, G. Leofanti, M. Padovan, G. Busca, An FT-IR and reactor study of the dehydrochlorination activity of $\mathrm{CuCl}_{2}$ $\gamma-\mathrm{Al}_{2} \mathrm{O}_{3}$-based oxychlorination catalysts, J. Catal. 191 (2000) 354-363.

[33] G. Leofanti, A. Marsella, B. Cremaschi, M. Garilli, A. Zecchina, G. Spoto, S. Bordiga, P. Fisicaro, G. Berlier, C. Prestipino, G. Casali, C. Lamberti, Aluminasupported copper chloride 3. Effect of exposure to ethylene, J. Catal. 202 (2001) 279-295.

[34] G. Leofanti, A. Marsella, B. Cremaschi, M. Garilli, A. Zecchina, G. Spoto, S. Bordiga, P. Fisicaro, C. Prestipino, F. Villain, C. Lamberti, Alumina-supported copper chloride: 4. Effect of exposure to $\mathrm{O}_{2}$ and $\mathrm{HCl}$, J. Catal. 205 (2002) 375 381.

[35] N.B. Muddada, U. Olsbye, T. Fuglerud, S. Vidotto, A. Marsella, S. Bordiga, D. Gianolio, G. Leofanti, C. Lamberti, The role of chlorine and additives on the density and strength of Lewis and Brønsted acidic sites of $\gamma-\mathrm{Al}_{2} \mathrm{O}_{3}$ support used in oxychlorination catalysis: a FTIR study, J. Catal. 284 (2011) 236-246.

[36] R.V. Carrubba, J.L. Spencer, Kinetics of the oxychlorination of ethylene, Ind Eng. Chem. Proc. Des. Dev. 9 (1970) 414-419.

[37] E.I. Gelperin, Y.M. Bakshi, A.G. Zyskin, Y.S. Snagovsky, A.K. Avetisov, Kinetics and mechanism of ethylene oxychlorination, Russ. Chem. Ind. 28 (1996) 356 363.

[38] D. Gianolio, N.B. Muddada, U. Olsbye, C. Lamberti, Doped-CuCl $/ 2 \mathrm{Al}_{2} \mathrm{O}_{3}$ catalysts for ethylene oxychlorination: influence of additives on the nature of active phase and reducibility, Nucl. Instr. Meth. Phys. Res. B. 284 (2012) 53-57.

[39] N.B. Muddada, U. Olsbye, G. Leofanti, D. Gianolio, F. Bonino, S. Bordiga, T. Fuglerud, S. Vidotto, A. Marsella, C. Lamberti, Quantification of copper phases, their reducibility and dispersion in doped- $\mathrm{CuCl}_{2} / \mathrm{Al}_{2} \mathrm{O}_{3}$ catalysts for ethylene oxychlorination, Dalt. Trans. 39 (2010) 8437-8449.

[40] A.J. Magistro, J.A. Cowfer, Oxychlorination of ethylene, J. Chem. Educ. 63 (1986) 1056-1058.

[41] D. Shi, R. Hu, Q. Zhou, C. Li, Effect of Cr-doping on $\mathrm{CuCl}_{2}-\mathrm{KCl}-\mathrm{CeO}_{2} / \gamma-\mathrm{Al}_{2} \mathrm{O}_{3}$ catalysts for ethane oxychlorination, Appl. Catal. A Gen. 506 (2015) 91-99.

[42] S.A. Kurta, Investigating active centers of industrial catalysts for the oxidative chlorination of ethylene on a $\gamma-\mathrm{Al}_{2} \mathrm{O}_{3}$ surface, Catal. Ind. 3 (2011) 136-143.

[43] S.A. Kurta, Catalysis of ethylene oxychlorination into 1,2-dichlorethane in the presence of $\mathrm{CuCl}_{2} / \mathrm{CuCl}$ active centres on the surface of $\gamma-\mathrm{Al}_{2} \mathrm{O}_{3}$, Chem. Chem. Technol. 6 (2012) 1-8.

[44] M. Scharfe, P.A. Lira-Parada, V. Paunovic, M. Moser, A.P. Amrute, J. PérezRamírez, Oxychlorination-dehydrochlorination chemistry on bifunctiona ceria catalysts for intensified vinyl chloride production, Angew. Chem. Int Ed. 55 (2016) 3068-3072.

[45] M. Scharfe, P.A. Lira-Parada, A.P. Amrute, S. Mitchell, J. Pérez-Ramírez, Lanthanide compounds as catalysts for the one-step synthesis of vinyl chloride from ethylene, J. Catal. 344 (2016) 524-534.

[46] R. Lin, A.P. Amrute, J. Pérez-Ramírez, Halogen-mediated conversion of hydrocarbons to commodities, Chem. Rev. 117 (2017) 4182-4247.

[47] F. Hess, H. Over, Rate-determining step or rate-determining configuration? The Deacon reaction over $\mathrm{RuO}_{2}(110)$ studied by DFT-based KMC simulations, ACS Catal. 7 (2017) 128-138.

[48] D. Teschner, G. Novell-Leruth, R. Farra, A. Knop-Gericke, R. Schlögl, L. Szentmiklósi, M. González Hevia, H. Soerijanto, R. Schomäcker, J. PérezRamírez, N. López, In situ surface coverage analysis of $\mathrm{RuO}_{2}$-catalysed $\mathrm{HCl}$ oxidation reveals the entropic origin of compensation in heterogeneous catalysis, Nat. Chem. 4 (2012) 739-745.

[49] D. Teschner, R. Farra, L. Yao, R. Schlögl, H. Soerijanto, R. Schomäcker, T. Schmidt, L. Szentmiklósi, A.P. Amrute, C. Mondelli, J. Pérez-Ramírez, G. NovellLeruth, N. López, An integrated approach to Deacon chemistry on $\mathrm{RuO}_{2}$-based catalysts, J. Catal. 285 (2012) 273-284.
[50] M. Moser, V. Paunović, Z. Guo, L. Szentmiklósi, M.G. Hevia, M. Higham, N. López, D. Teschner, J. Pérez-Ramírez, Interplay between surface chemistry and performance of rutile-type catalysts for halogen production, Chem. Sci. 7 performance of rutile
(2016) 2996-3005.

[51] T. Hibi, H. Nishida, H. Abekawa, Process for producing chlorine, US 5871707 1999.

[52] G. Kresse, J. Furthmüller, Efficiency of ab-initio total energy calculations for metals and semiconductors using a plane-wave basis set, Comput. Mater. Sci. 6 (1996) 15-50.

[53] G. Kresse, J. Furthmüller, Efficient iterative schemes for ab initio total-energy calculations using a plane-wave basis set, Phys. Rev. B. 54 (1996) 1116911186.

[54] H.J. Monkhorst, J.D. Pack, Special points for Brillouin-zone integrations, Phys. Rev. B. 13 (1976) 5188-5192.

[55] C.-E. Boman, Refinement of the crystal structure of ruthenium dioxide, Acta Chem. Scand. 24 (1970) 116-122.

[56] N. López, J. Gómez-Segura, R.P. Marín, J. Pérez-Ramírez, Mechanism of HCl oxidation (Deacon process) over $\mathrm{RuO}_{2}$, J. Catal. 255 (2008) 29-39.

[57] J.P. Perdew, K. Burke, M. Ernzerhof, Generalized gradient approximation made simple, Phys. Rev. Lett. 77 (1996) 3865-3868.

[58] P.E. Blöchl, Projector augmented-wave method, Phys. Rev. B. 50 (1994) 1795317979.

[59] S. Pogodin, N. López, A more accurate kinetic Monte Carlo approach to a monodimensional surface reaction: The interaction of oxygen with the $\mathrm{RuO}_{2}(110)$ surface, ACS Catal. 4 (2014) 2328-2332.

[60] G. Henkelman, B.P. Uberuaga, H. Jónsson, A climbing image nudged elastic band method for finding saddle points and minimum energy paths, J. Chem. Phys. 113 (2000) 9901-9904.

[61] M. Álvarez-Moreno, C. de Graaf, N. López, F. Maseras, J.M. Poblet, C. Bo, Managing the computational chemistry big data problem: the ioChem-BD platform, J. Chem. Inf. Model. 55 (2015) 95-103.

[62] https://dx.doi.org/10.19061/iochem-bd-1-38.

[63] P.J. Linstrom, W.G. Mallard (Eds.), NIST Chemistry WebBook, NIST Standard Reference Database Number 69, National Institute of Standards and Technology, Gaithersburg, MD.

[64] M. Moser, C. Mondelli, A.P. Amrute, A. Tazawa, D. Teschner, M.E. Schuster, A. Klein-Hoffman, N. López, T. Schmidt, J. Pérez-Ramírez, $\mathrm{HCl}$ oxidation on $\mathrm{IrO}_{2}-$ based catalysts: from fundamentals to scale-up, ACS Catal. 3 (2013) 28132822.

[65] H. Over, Ruthenium dioxide, a fascinating material for atomic scale surface chemistry, Appl. Phys. A Mater. Sci. Process. 75 (2002) 37-44.

[66] S. Zweidinger, D. Crihan, M. Knapp, J.P. Hofmann, A.P. Seitsonen, C.J. Weststrate, E. Lundgren, J.N. Andersen, H. Over, Reaction mechanism of the oxidation of $\mathrm{HCl}$ over $\mathrm{RuO}_{2}(110)$, J. Phys. Chem. C 112 (2008) 9966-9969.

[67] A.P. Seitsonen, H. Over, Oxidation of $\mathrm{HCl}$ over $\mathrm{TiO}_{2}$-supported $\mathrm{RuO}_{2}$ : a density functional theory study, J. Phys. Chem. C 114 (2010) 22624-22629.

[68] $\mathrm{H}$. Over, Atomic-Scale Understanding of the $\mathrm{HCl}$ oxidation over $\mathrm{RuO}_{2}$, a nove Deacon process, J. Phys. Chem. C 116 (2012) 6779-6792.

[69] Y. Segura, N. López, J. Pérez-Ramírez, Origin of the superior hydrogenation selectivity of gold nanoparticles in alkyne + alkene mixtures: Triple- versus double-bond activation, J. Catal. 247 (2007) 383-386.

[70] D. Crihan, M. Knapp, S. Zweidinger, E. Lundgren, C.J. Weststrate, J.N. Andersen, A.P. Seitsonen, H. Over, Stable Deacon process for $\mathrm{HCl}$ oxidation over $\mathrm{RuO}_{2}$, Angew. Chem. Int. Ed. 47 (2008) 2131-2134.

[71] G. Novell-Leruth, G. Carchini, N. López, On the properties of binary rutile $\mathrm{MO}_{2}$ compounds, M = Ir, Ru, Sn, and Ti: a DFT study, J. Chem. Phys. 138 (2013) 194706. 